\title{
The Use of Chloroform by British Army Surgeons during the Crimean War
}

\author{
HENRY CONNOR*
}

The use of chloroform during the Crimean War was determined by the opinions and experience of medical staff and by the availability of chloroform on the battlefields and in the military hospitals. This paper will begin by reviewing medical opinion on the value of chloroform in military surgery at the start of the war, and after examining the availability and use of chloroform during the war, it will conclude with an examination of medical opinion at the end of the war. A brief chronology of the major military events is given in Table 1.

\section{Medical Opinion in the Army at the Start of the War}

On 12 May 1847, less than six months after the arrival of anaesthesia in Britain, John Snow delivered a lecture on the use of ether in surgical operations to the medical members of the United Services Institution. ${ }^{1}$ In this lecture Snow, with his characteristic insight, foresaw many of the potential benefits of anaesthesia in military practice. Some of these, which were later to be realized during the Crimean War, have been italicized in the following quotations from Snow's paper. He argued that

... the pain of a surgical operation is greater than that of the wound itself. Whilst the latter is instantaneous, and its approach unknown, the approach of an operation is seen, and its cuts are necessarily deliberate; . . . The blessing would be great of merely preventing this pain, but $I$ am firmly convinced that the exhibition of ether will be attended with the still greater advantage of saving many lives. A great part of the danger of an operation consists in the pain of it, which gives a shock to the system from which it is sometimes unable to recover. If an operation is performed during or immediately after an action, the wounded man suffers two shocks together-that of his wound and that of the operation, which although, singly, his frame might sustain, united, perhaps it cannot. If, on the other hand, a secondary operation, as it is called, has to be performed sometime

*Dr H Connor, Consultant Physician, County Hospital, Hereford HR1 2ER.

This paper would not have been possible without access to the archive of the Royal Army Medical Corps (RAMC) in the Contemporary Medical Archives Centre (CMAC) at the Wellcome Institute for the History of Medicine; quotations and data from the Archives are reproduced by courtesy of the Wellcome Trustees. I am most grateful to Shirley Dixon in the CMAC, who catalogued the Archive, for guiding me towards the relevant sections. I am also grateful to Dr Brian Davies for lending me copies of some of the Parliamentary Papers which are quoted in the text, to the library staff at the British Medical Association and to Janet Ball, librarian at the Hereford Postgraduate Medical Centre, for assistance in locating some of the references, and to Pat Rossi for typing the manuscript. I thank the Governors of the Hereford Postgraduate Medical Centre for a Bursary which contributed to the costs of the research. Anyone researching the medical history of the Crimean War owes an immense debt to the pioneering work of the late Mr John Shepherd.

$1 \mathrm{~J}$ Snow, 'Inhalation of vapour of ether in surgical operations', Lancet, 1847, i: 551-4, p. 553. 


\section{Henry Connor}

Table 1

Chronology of events relevant to the text

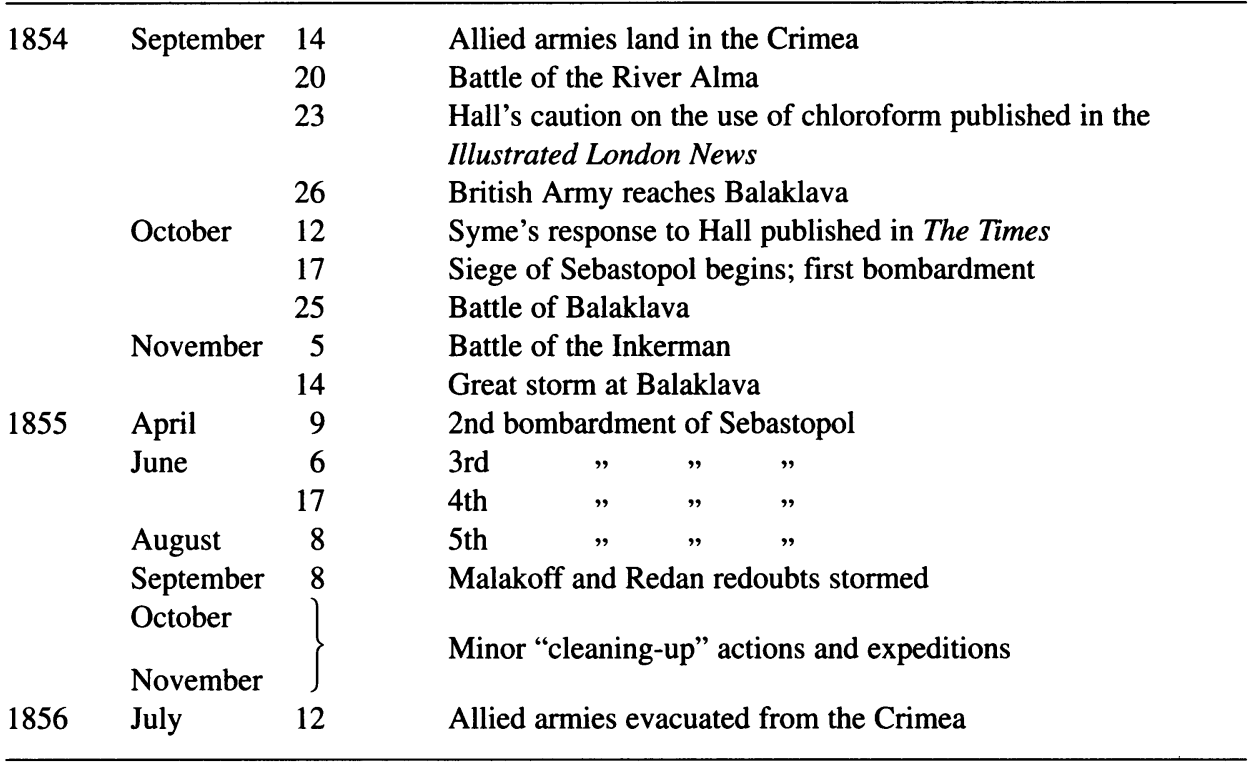

afterwards in the hospital, he is rendered more nervous and susceptible of pain by his illness and suffering. . . I I believe that ether will give the surgeon a greater choice in selecting between cases for immediate and subsequent operation, for dread of the knife helps to cause and keep up the faintness and collapse, which often prevent the surgeon from operating at once. The ether and apparatus will not add anything to the necessary baggage, for it will stand in the stead of a much greater weight of brandy. ... During the operation it will prevent faintness, which arises more from pain than loss of blood, which is seldom great. It usually acts, also, as a stimulate in itself, and I do not remember to have seen wine or brandy given in the operating theatre of St George's Hospital more than once since January.

Snow went on to describe some of the operations, for which he had anaesthetized, which were of particular relevance to military surgeons. There were twelve amputations (thigh 8; leg 2; forearm 2), with two deaths, both after thigh amputations in weak and emaciated patients, "and I may observe, that two out of eight is below the usual number of deaths after this operation. Operations for necrosis somewhat resemble several undertaken for the removal of bullets and other extraneous bodies. Of these there have been four in the hospital, and the patients did extremely well".

Despite the potential benefits of anaesthesia, as described to military surgeons by Snow, there is little evidence of its use by British army surgeons in war injuries before 1854. John Shepherd, who noted that military surgeons were frequent contributors to the medical journals of the time, could find only one definite report, prior to 1854, of anaesthesia being used for wounds received on the battlefield. ${ }^{2}$ This was a letter from an assistant-surgeon

2 J A Shepherd, 'The smart of the knife-early anaesthesia in the services', J. R. Army Med. Corps, 1985, 131: 109-15. 
in the Indian Medical Service, who wrote following an action: "After attending my own wounded, I proceeded to those of the enemy, and out of these 49 cases, I had 18 amputations to perform, all under the influence of chloroform; and, with the exception of 3 cases . . . every man recovered". ${ }^{3}$ Further extensive research by Shepherd did not reveal any other references to use of anaesthesia by British army surgeons before $1854 .^{4}$

Although there appears to have been little experience of military anaesthesia in the British army, in Russia Nikolai Pirogov had used ether extensively and successfully during the Caucasus campaign of 1847.5 He reported his results on several occasions between 1847 and 1852, but it is perhaps unlikely that British doctors would have been aware of reports in Russian language publications. They would, however, have known of the opinions of Parisian surgeons during the riots and insurrection in that city in 1848, even if they did not read French journals, because translations of the surgeons' experiences were reported in the Lancet. Jules Roux was said to have used chloroform seven times in wounded patients "without the least unpleasant symptom", 6 but Alfred Velpeau thought that as "chloroform evidently depresses the nervous system, and as great prostration always exists in patients who have received gunshot wounds, it is advisable to refrain from any anaesthetic means". 7 Dr Charles Kidd, who was in Paris at the time, commented that "anaesthetic agents have, in almost every instance, proved highly safe and useful", and, though he also noted that mortality after amputation was twice what it had been in the Peninsular War, he attributed this to the facts that the Parisian hospitals were overwhelmed by the immensely high casualty rate and that several hospitals were themselves under siege. ${ }^{8}$ Writing after the war, Kidd claimed that further evidence for the benefits of chloroform in military surgery had been provided by its use during the Russian invasion of Hungary and in the annexation of the Punjab in $1849,{ }^{9}$ but references to support these claims have not been found.

Immediately before the British army's embarkation, at Varna in Bulgaria, for the Crimea, Dr John Hall, the Principal Medical Officer, issued a 'Memorandum for the information of Medical Officers taking the field for active service'. ${ }^{10}$ It was this memorandum which contained Hall's much quoted caution against the use of chloroform:

Dr Hall takes this opportunity of cautioning medical officers against the use of chloroform in the severe shock of serious gunshot wounds, as he thinks few will survive where it is used. But as public opinion, founded perhaps on mistaken philanthropy, he knows is against him, he can only caution medical officers, and entreat that they will watch its effects; for however barbarous it may appear, the smart of the knife is a powerful stimulant; and it is much better to hear a man bawl lustily than to see him sink silently into the grave.

${ }^{3}$ W B McEgan, 'Chloroform in India', Lancet, 1851, 2: 96.

4 J A Shepherd, The Crimean doctors: a history of the British medical services in the Crimean War, Liverpool University Press, 1991, pp. 57-61.

5 T Sorokina, personal communication.

${ }^{6}$ Lancet, 1848 , ii: $316-17$, p. 316.

${ }^{7}$ Alfred Velpeau, 'General considerations on gunshot wounds; primary and secondary amputation', Lancet, 1848, ii: 3-5, p. 5.

${ }^{8} \mathrm{C}$ Kidd, 'Observations in the Paris hospitals during the Revolution of June', Medical Times, 1848, 18: 268-9, 287-9, 318-20, 369-70; ibid., 19: 23-5, and especially, pp. 54-5.

${ }^{9}$ Idem, 'Safety of chloroform in gun-shot wounds', Med. Times Gaz., 1856, i: 340-1.

${ }^{10}$ For an original copy see the Longmore Papers, in the RAMC Muniments Collection, CMAC, Wellcome Institute for the History of Medicine, RAMC 1139, LP 9/11. John Hall was knighted in 1856. His papers are held in the CMAC, see notes 30 and 33 below. 


\section{Henry Connor}

On 23 September 1854, the Illustrated London News published in full the 'Instructions to troops' in the invading army, which included Hall's memorandum. Some three weeks later, after the furore caused by the inadequate arrangements for the care of the wounded at the battle of the Alma and their transport to Scutari had already been vented in the press, a fierce argument broke out in The Times concerning Hall's advice on chloroform. On 12 October, the newspaper published a letter from James Syme who wrote:

... it seems requisite to state, as a result of long and ample experience in opposition to what Dr Hall "thinks" on the subject, that chloroform does not increase the danger of operations performed during a state of exhaustion, however extreme; that pain, instead of being a "powerful stimulant", most injuriously exhausts the nervous energy of a weak patient; and that, therefore, so long as the safety of the operation may be in question, chloroform proves useful directly in proportion to the severity of the injury or disease and the degree of exhaustion or shock. ${ }^{11}$

There was an immediate response when, on the next day, a letter appeared from a correspondent who signed himself "A Military Surgeon":

Chloroform is a powerful depressant of vital action. Yesterday at University College Hospital another victim fell sacrifice to it; and it is cheering to know that, at several of the London hospitals, the perfectly safe practice of benumbing the part with cold, previously to its incision, is now being substituted for chloroform in a large class of operations. ${ }^{12}$

Such opinions were not confined to military surgeons. In the same month Dr James Arnott published detailed 'Instructions for using benumbing cold in operations' ${ }^{13}$ and a few months later Thomas Wakley Junior wrote a letter to his father's journal confirming Arnott's results. ${ }^{14}$ This letter was also noticed by the lay press, ${ }^{15}$ which suggests that there must have been public interest in safer alternatives to chloroform at this time. However, the majority opinion in favour of chloroform was reflected in a leading article entitled 'Chloroform on the battlefield' in the Association (subsequently British) Medical Journal. The editor noted that Dr Hall's opinion was "opposed to our observation on the effects of chloroform in civil practice", and cited, in support of his argument, "the statistics of the results of amputations under anaesthesia, collected by Dr Simpson a few years ago". ${ }^{16}$ James Young Simpson's study in fact related to amputations under ether, rather than chloroform, and was not, by modern standards, an adequately controlled trial. It did, however, appear to show that amputations of the thigh, leg and arm carried a mortality of 23 per cent under ether, whereas without ether the mortality was between 29 and 40 per cent. ${ }^{17}$ Some military surgeons regarded Simpson's data as irrelevant, contending that injuries due to gunshot wounds, and their associated shock, were fundamentally different from the operations due to illnesses seen in civilian practice. This view, which ignored the fact that some civilian amputations were in fact due to gunshot wounds, ${ }^{18}$ persisted even after the war. ${ }^{19}$

${ }^{11}$ The Times, 12 Oct. 1854 , p. 9 , col. 1.

12 Ibid., 13 Oct. 1854 , p. 5 , col. 5 .

$13 \mathrm{~J}$ Arnott, 'Instructions for using benumbing cold in operations', Med. Times Gaz., 1854, ii: 488-90.

${ }^{14} \mathrm{~T}$ Wakley, 'Anaesthesia by cold in surgical operations', Lancet, 1855, i: 140.

${ }^{15}$ Eddowe's Shropshire Journal, 7 Feb. 1855, p. 7.

${ }^{16}$ Leading article, 'Chloroform on the battlefield', Assoc. med. J., 1854, 2: 1029-30, p. 1029.
17 J Y Simpson, 'Does etherisation increase or decrease the mortality attendant upon surgical operations?', Monthly J. med. Sci., 1848, 8: 697-710.

${ }^{18} \mathrm{R}$ Hodges, "Amputation at the shoulder-joint under the influence of chloroform in a case of gunshot wound', Assoc. med. J., 1854, 2: 1142-3.

$19 \mathrm{~J}$ Mouat, in report of Crimean Medical and Surgical Society meeting, Med. Times Gaz., 1856, ii: 225-7. 
It is in the context of these differing opinions on the safety and value of chloroform that Hall's caution on its use must be judged. If his opinion owed more to the views of men like Velpeau and Arnott rather than to those of Snow, Simpson and Syme, and, if that opinion was subsequently to be proved wrong, he was certainly not alone in this. ${ }^{20}$ That his opinion was likely to be unpopular, he himself recognized in the original memorandum. He wrote later that he had "incurred much public odium for a wellintentioned, but carelessly worded caution", 21 and this was echoed by Dr James Mouat, one of his Deputy Inspector-Generals, who commented, "I am not about to enter into the question as to whether that caution might not have been more carefully and judiciously worded; for, no doubt, it would have been differently expressed, if intended for the perusal of a popular, instead of a professional public".22 George Macleod believed that Hall's choice of words had been open to misinterpretation: "I have reason to know that he himself did not mean them, as was at the time supposed, as a prohibition on its use, but simply as a caution against its careless and indiscriminate employment". ${ }^{23}$ In August 1854 Hall was not to know that the Crimean campaign would be reported more intensively by the lay press than any previous war, and would not have expected to find his detailed memorandum reprinted, verbatim, in a popular magazine.

The opinion of the Principal Medical Officer, expressed in a printed memorandum, must have influenced the practice of his subordinates, at least in the initial stages of the war, but it is difficult to judge the extent of this influence from the surviving evidence. $R$ J Mackenzie believed that "Dr Hall's order is intended to discourage the use of it [chloroform] altogether. No one, I should think, will take any notice of it", ${ }^{24}$ and Dr George Pyemont Smith, a civilian volunteer who arrived in Scutari in mid-November 1854, wrote that

The celebrated manifesto of Dr Hall against chloroform had not much attention paid to it at Scutari. I had been accustomed to the use of chloroform, but certainly had never seen it given to the extent that it was employed there. An operation was never commenced before the patient was fully under the influence of chloroform. ${ }^{25}$

On the other hand a Dr Tuffnell, a civilian surgeon from Dublin, felt powerless "with an order promulgated against the use of chloroform", and returned home. ${ }^{26}$

There is some evidence that the Medical Officers of the 2nd Division may have been particularly influenced by Hall's memorandum. An addendum to the sixth edition of George Guthrie's Commentaries on surgery, which was published privately at the end of 1855 , stated that "Chloroform has been freely administered in all the Divisions of the Army save the Second."27 The Principal Medical Officer of the 2nd Division was Staff

${ }^{20} \mathrm{G}$ H B MacLeod, 'Notes on the surgery of the war', Edinb. med. J., 1856, 1: 984-1001, especially pp. 992-3.

${ }^{21}$ Health of the army in Turkey and Crimea: Paper, being medical and surgical history of the British army which served in Turkey and the Crimea during the Russian war, Parliamentary Papers 1857-58, vol. xxxviii, pts 1 and 2 (hereafter Medical and surgical history), pt 2, p. 269.

22 Report of Crimean Medical and Surgical Society meeting, op. cit., note 19 above, p. 225.
23 Macleod, op. cit., note 20 above, p. 992.

24 Obituary, 'The late Dr R J Mackenzie', Monthly J. med. Sci., 1854, 19: 474-8.

25 G Pyemont Smith, 'On military medical practice in the East', Lancet, 1855, i: 482-3, 509-10, 582, and, especially, 647-8.

${ }^{26}$ Medical News, 'Amputations in the Crimea', Lancet, 1855, i: 304.

${ }^{27}$ Longmore Pamphlets, RAMC 423, vol. 5, Paper 1. 


\section{Henry Connor}

Surgeon Gordon, and Guthrie's addendum contained examples, supplied by Gordon, of successful major amputations performed without the use of chloroform. He was one of the minority of surgeons in the Crimean Medical and Surgical Society who were, at the end of the war, still expressing considerable reservations about chloroform in major surgery, and claimed that the Medical Officers of the Division "generally agreed with him in the inadvisability of employing chloroform in serious cases". ${ }^{28}$ However, this latter statement was subsequently challenged by Dr Burke, one of the Regimental Medical Officers in the 2nd Division. He was supported by Deputy Inspector-General James Williams, who said it was "known that many cases in the 2nd Division were operated on under chloroform", but added that "The misconception may have arisen from supposing the 2nd Division carried out more fully than others the recommendation given at the commencement of the war". 29

If Hall's caution did have an influence on the use of chloroform, it would seem that this was probably limited to the early months of the war, and then only in those regiments or divisions where the senior Medical Officers happened to concur with Hall's conservative opinion. Such, then, was the diversity of medical opinion at the start of the war. The following sections review the availability and use of chloroform at different stages during the war.

\section{The Availability and Use of Chloroform at the Alma and during Transport of the Wounded to Scutari}

By mid-August 1854, $180 \mathrm{lbs}$ of chloroform had been shipped to the army (Table 2). Of this, $110 \mathrm{lbs}$ had accompanied the army to Varna in Bulgaria, where $32 \mathrm{lbs} 8 \mathrm{oz}$ had been issued to Divisions, with $77 \mathrm{lbs} 8 \mathrm{oz}$ held in store on 17 August. ${ }^{30}$ The other $70 \mathrm{lbs}$ were presumably in the hospital store at Scutari. At Varna the Light, 2nd and 3rd Divisions were each issued with $10 \mathrm{lbs}$ of chloroform between June and 7 September, when the army sailed for the Crimea. ${ }^{31}$ Although no records have been found, it seems probable that the 1st, 4th and Cavalry Divisions would each have been issued with the same quantity, before embarkation, leaving $47 \mathrm{lbs} 8 \mathrm{oz}$ in store at Varna. This was further augmented by stocks on the Medway, which had sailed with $60 \mathrm{lbs}$ on board, but which called at Balaklava on 2 September where $30 \mathrm{lbs}$ were transferred to the John Masterman store ship. ${ }^{32}$ The remaining $30 \mathrm{lbs}$ were presumably unloaded when she reached Varna on 4 September, making a total of $77 \mathrm{lbs} 8 \mathrm{oz}$ in store in Varna on that date. After the army left Varna, the hospital and purveyor's stores were transferred, not to the Crimea, but to Scutari, though the transfer did not occur until some time after 20 October. ${ }^{33}$ Therefore, of the $240 \mathrm{lbs}$ of chloroform which had arrived in the East before the battle of the Alma on 20 September, at least $177 \mathrm{lbs} 8 \mathrm{oz}$ were not available to surgeons after the battle; $70 \mathrm{lbs}$ being in Scutari, $77 \mathrm{lbs} 8 \mathrm{oz}$ in store at Varna, and $30 \mathrm{lbs}$ on the John Masterman store ship in Balaklava harbour, which the army did not reach until some days after the battle. The Purveyor's

\footnotetext{
${ }^{28}$ Report of Crimean Medical and Surgical Society meeting, Med. Times Gaz., 1856, ii: 252-4, p. 252.

29 Ibid., pp. $297-300$, p. 300.

30 The Hall Papers, RAMC 397, FRS 1/1a.

31 Ibid., FRS 1/2, 1/13a, 1/15.
}

\footnotetext{
32 Parliamentary report upon the state of the hospitals of the British Army in the Crimea and Scutari, London, HMSO, 1855 (hereafter, Hospitals report), pp. 57-8.

${ }^{33}$ Hall Diaries transcript, RAMC 524/15/6.
} 


\section{The Use of Chloroform during the Crimean War}

Table 2

Supplies of chloroform sent to Turkey and the Crimea 1854-1856

\begin{tabular}{lcr}
\hline Vessel & Date of Arrival & Chloroform (lbs) \\
\hline Wrights & 16.5 .54 & 40 \\
Balbec & 20.5 .54 & 140 \\
Medway & 4.9 .54 & 60 \\
Army and Navy & 19.1 .55 & 100 \\
Eagle & 19.1 .55 & 50 \\
Whitley Park & unknown & 150 \\
Black Sea & 15.4 .55 & 100 \\
Stella & 18.4 .55 & 100 \\
Arethusa & 21.5 .55 & 50 \\
Eagle & $? .7 .55$ & 150 \\
Black Prince & 29.8 .55 & 208 \\
Caroline & 19.1 .56 & 450 \\
Peninsula & 21.3 .56 & 50 \\
& & 1648 \\
\hline
\end{tabular}

Source: Medical and surgical history, see note 21 above, pt 1, p. 555.

Reserve Stores, which did accompany the army, contained 5 lbs of chloroform, but none of this had been issued before 27 September, ${ }^{34}$ and in fact only $8 \mathrm{oz}$ were issued from this store during October and a further $1 \mathrm{lb} 8 \mathrm{oz}$ during November. ${ }^{35}$

The regimental surgeons would certainly have had access to stocks of chloroform in their field panniers, which should have contained $8 \mathrm{oz}$ per regiment, ${ }^{36}$ and this quantity was corroborated by one of the regimental surgeons at the battle of the Alma. ${ }^{37}$ As there were 38 regiments in the Crimea at the time, ${ }^{38}$ there should have been a minimum of 19 lbs of chloroform available to surgeons after the battle. How much of the $60 \mathrm{lbs}$ which had been issued to the six divisions was available is unclear. If all of it had been available, there would have been a maximum of $79 \mathrm{lbs}$ for use after the battle. There are two reasons why there was probably much less than this. First, some of the divisional stocks were probably used to make up the allocation of $8 \mathrm{oz}$ per regiment. Whether this was so cannot be ascertained from the surviving records. Detailed receipts for this period are available only for the Light Division, which received its $10 \mathrm{lbs}$ allocation on 22 June and had issued all except $8 \mathrm{oz}$ by 30 September. ${ }^{39}$ Whether these issues had been made as the initial $8 \mathrm{oz}$ allocations to each regiment or to replace stocks used in the battle on 20 September cannot be determined. Second, whatever divisional stocks remained and accompanied the army to the Crimea should have been in detachment and regimental medicine chests. ${ }^{40}$ However

\footnotetext{
${ }^{34}$ Hospitals report, op. cit., note 32 above p. 7; RAMC 397, FRS 5/1, see note 30 above.

35 RAMC 397, FRS 5/2 and FRS 5/3.

${ }^{36}$ Hospitals report, op. cit., note 32 above, p. 127.

${ }^{37}$ Anon., 'Surgery of the war', Lancet, 1854, ii: 517-18.
}

\footnotetext{
${ }^{38}$ RAMC 397, FRM 2/1, see note 30 above.

39 Ibid., FRS 1/2.

${ }^{40}$ Report of the Commissioners appointed to inquire into the regulations affecting the sanitary condition of the army, the organisation of military hospitals, and the treatment of the sick and wounded;
} 


\section{Henry Connor}

most of these chests were either left behind at Varna, or re-shipped as soon as the army landed in the Crimea because of the almost total lack of transport. ${ }^{41}$ Only the 62 nd Regiment is certainly known to have retained its chest and was "indebted to the courtesy of the French commissariat for having brought it to the camp". ${ }^{42}$ Most of the chests eventually reached the Crimea but were still in the Apothecary's Stores at Balaklava on 5 January $1855 . .^{43}$ Inventories of the contents of those belonging to the 7th, 19th and 23rd Regiments in February 1855 made no mention of the chloroform which they should have contained, ${ }^{44}$ which may imply that it had been plundered to supplement shortages during the preceding months.

In summary, the surviving records suggest that there was a minimum of $19 \mathrm{lbs}$ of chloroform available from official supplies, and it is very unlikely that there was much more than this, as it is improbable that any significant amount from the divisional stores was available following the battle of the Alma.

Some of the chloroform may have been used for purposes other than anaesthesia. It was sometimes used in the treatment of tetanus, but there were only 23 recognized cases of tetanus during the whole of the Crimean War and only a few were given chloroform. ${ }^{45}$ It was also used by some doctors in the treatment of delirium tremens, ${ }^{46}$ of which there were 281 cases admitted to hospital during the campaign. ${ }^{47}$ Shepherd states that it had been recommended by inhalation for the spasms of cholera which affected huge numbers of soldiers in Bulgaria before the army embarked for the Crimea, as well as in the Crimea itself; ${ }^{48}$ however, there is no evidence that chloroform was commonly used for this purpose.

The amount of chloroform which was used for non-anaesthetic purposes before the battle of the Alma was probably quite small, and may have been counter-balanced by the small quantities taken in the private stores of some civilian surgeons. If it is assumed that there were, perhaps, 25-30 lbs available for anaesthesia, and if it is also assumed that an average of $2 \mathrm{oz}$ was used for each anaesthetic, ${ }^{49}$ then there would have been sufficient for 200 to 240 anaesthetizations. If the chloroform had been readily available, where and when it was needed, even this small proportion of the total which had been shipped to the East might have been sufficient to anaesthetize those who needed major surgery after the battle of the Alma, where the number of wounded was $1722 . .^{50}$ Of these, about two-thirds were categorized as having severe wounds, but many of the wounds were probably not amenable to operative intervention, because, throughout the entire war, amputations, which would have been the main indication for anaesthesia, did not amount to more than 5 per cent of all the wounded. ${ }^{51}$ However, the distribution of chloroform did not correspond, either at divisional or regimental levels, with where it was needed. For example, three of the six divisions suffered 98 per cent of the casualties (Table 3). At a

with evidence and appendix, London, HMSO, 1858, Appendix 79, (hereafter Sanitary report), p. 137, Correspondence No. 602, letter 5 from D Dumbreck to $\mathrm{T}$ Alexander.

${ }^{41}$ Hospitals report, op. cit., note 32 above, Regimental Surgeons' reports, pp. 68-153.

42 Ibid., p 136.

43 RAMC 397, FRS 1/18, see note 30 above.

44 Ibid., FCO 32/16b, 21c, 21d.

${ }^{45}$ Medical and surgical history, op. cit., note 21 above, pt 2, pp. 279-85.

${ }^{46}$ Report of Crimean Medical Society meeting, Med. Times Gaz., 1856, ii: 376-8, p. 378.

${ }^{47}$ Medical and surgical history, op. cit., note 21 above, pt 2, Table A, unpaginated, following p. 251.

${ }^{48}$ Shepherd, op. cit., note 4 above, p. 132.

49 Ibid., p. 132.

${ }^{50}$ RAMC 397, FRM 2/1, see note 30 above.

51 Ibid., FRM 1/1-7 and FRM 7/10. 
The Use of Chloroform during the Crimean War

Table 3

The casualty rates in different divisions at the Battle of the Alma

\begin{tabular}{lrrr}
\hline Division & Killed & Wounded & Missing \\
\hline Calvalry & 0 & 0 & 0 \\
First & 46 & 551 & 1 \\
Second & 86 & 409 & 3 \\
Third & 1 & 38 & 3 \\
Fourth & 1 & 3 & 0 \\
Light & 207 & 771 & 11 \\
\hline
\end{tabular}

Source: RAMC 397 FRM 2/1, see note 30 above.

regimental level each regiment had, in theory, $8 \mathrm{oz}$ of chloroform, but in the Light Division the distribution among the regiments was very uneven, and bore no relationship to the casualty rates in the different regiments (Table 4). The 7th Fusiliers, which had one of the highest casualty rates, apparently had no chloroform, whereas the 88th Regiment, which suffered only light casualties, had received $2 \mathrm{lbs} 8 \mathrm{oz}$ by 30 September. It is, of course, possible that the 7th Fusiliers had obtained supplies from other sources; for example, the 33rd Regiment received an additional $2 \mathrm{lbs}$ from an unspecified source at some time between October 1854 and January 1855,52 and between 1 September and 31 December 1854 a number of regiments received supplies directly from the Dispenser in charge in the Crimea ${ }^{53}$ instead of via the usual distribution from divisional stores, most of

Table 4

The Light Division-Stocks of chloroform and casualties at the Battle of the Alma

\begin{tabular}{|c|c|c|c|c|}
\hline \multirow[t]{2}{*}{ Regiment/Detachment } & \multicolumn{2}{|c|}{$\begin{array}{c}\text { Issues of Chloroform } \\
22.6 .54-30.9 .54\end{array}$} & \multirow[t]{2}{*}{ Killed } & \multirow[t]{2}{*}{ Wounded } \\
\hline & lbs & ozs & & \\
\hline Artillery & & 8 & 12 & 20 \\
\hline Sappers and Miners & & - & - & 1 \\
\hline 7th Fusiliers & & - & 41 & 179 \\
\hline 19th Regiment & & 8 & 41 & 179 \\
\hline 23rd Fusiliers & & 8 & 51 & 157 \\
\hline 33rd Regiment & 1 & 8 & 56 & 183 \\
\hline 77th Regiment & 1 & 0 & 3 & 17 \\
\hline 88th Regiment & 2 & 8 & 4 & 17 \\
\hline 2nd Battalion Rifles & 2 & 8 & 11 & 39 \\
\hline Other Corps & & - & & \\
\hline General Hospital Staff & & 8 & & \\
\hline Remaining in Divisional Store & & 8 & & \\
\hline
\end{tabular}

Source: RAMC 397 FRS 1/2, FRM 2/1 see note 30 above.

$$
{ }^{52} \text { Ibid., FRS 1/3b. } \quad{ }^{53} \text { Ibid., FBS } 1 / 5 .
$$




\section{Henry Connor}

which had probably been left in Varna or on the ships which transported the army to the Crimea. However, it is likely that issues from the Dispenser were made only after the army reached Balaklava, six days after the battle of the Alma, when the Dispenser would have had access to his stores.

It is also known that some surgeons took their own supplies of chloroform with them. One of these was Dr R J Mackenzie, a civilian volunteer attached to the 79th Regiment. How much chloroform he had is not known, but he probably carried very little because "we are all to carry our kits. I weighed mine yesterday, and between knapsack, haversack, rations, etc, I shall have within a few ounces of $50 \mathrm{lbs}$ on my back!" Mackenzie died of cholera shortly after the battle of the Alma and his obituary recorded that "in addition to extracting numerous balls, and dressing a multitude of wounds, he performed 27 capital operations". 54 It seems improbable that his own private supply of chloroform would have been adequate for this workload. Like other surgeons he was probably "borrowing from another's small pannier stock when he could ill spare the loan. There was no general canteen for general purposes". 55

The official medical history of the war stated that "On the field at Alma, it [chloroform] was largely employed". 56 However, the information on the availability of chloroform at regimental level tends to corroborate the opinion of a surgeon on the battlefield that "the supply of chloroform was most limited", 57 and W G Watt, the surgeon to the 23rd Royal Welch Fusiliers, which had suffered 51 killed and 157 wounded, reported that "After the battle of Alma . . I I was also unable to procure a proper supply of chloroform, the divisional supply having been exhausted, and I could not procure it from the general hospital". 58

Following the battle, the majority of the wounded were transferred by boat from Balaklava to the hospitals in Scutari. Of the eleven transport ships used at this time, only five had been issued with chloroform by the Dispenser in charge at Balaklava (Table 5). The Andes received no chloroform at Balaklava, but had been equipped as a hospital ship at Varna in August 1854, when 2 lbs of chloroform were supplied. ${ }^{59}$ However, according to Shepherd, when the Andes reached the Crimea the master denied that there were any medical stores on board, ${ }^{60}$ though Dr John Tice, who was her senior surgeon when she left Balaklava on 22 September, reported that he "found everything requisite in the shape of medicine, comforts, instruments, appliances", and he described the supply of medicines as "ample", the supply of surgical instruments as "sufficient for every purpose", and the supply of materials and appliances as "abundant".61 Victor Bonham-Carter quotes, without giving the archive reference, from the papers of John Hall, who painted a very different picture.

The Andes and Cambria were told off by Admiral Boxer as Hospital Ships and were equipped at Varna for that purpose in August 1854 ... They were ill calculated for the service they were intended for, and the Captain of the Andes was a drunken ill-conditioned man and subsequently occasioned much embarrassment by trans-shipping the stores to another vessel—without giving notice or

\footnotetext{
54 Obituary, op. cit., note 24 above.

55 'Surgery of the war', op. cit., note 37 above.

${ }^{56}$ Medical and surgical history, op. cit., note 21 above, pt 2, p. 266.

${ }^{57}$ Anon., 'Treatment of the wounded in the Crimea', Med. Times Gaz., 1854, ii: 506-8, 507.
}

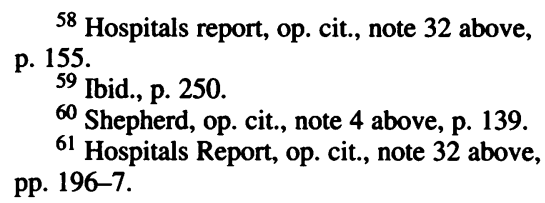


The Use of Chloroform during the Crimean War

Table 5

Transport ships carrying sick and wounded from the Crimea between 22 and 30 September 1854

\begin{tabular}{|c|c|c|c|c|c|}
\hline \multirow[t]{2}{*}{ Vessel } & \multirow[t]{2}{*}{ Date sailed } & \multirow{2}{*}{$\begin{array}{l}\text { Chloroform } \\
\text { on board }\end{array}$} & \multicolumn{2}{|c|}{ Sick and wounded } & \multirow{2}{*}{$\begin{array}{l}\text { Deaths on board } \\
\text { Source (2) }\end{array}$} \\
\hline & & & Source (1) & Source (2) & \\
\hline Vulcan & 22 Sept. (1)(2) & None (4) & $\begin{array}{l}455, \text { of which } \\
\text { wounded: } \\
? 435(1) ? 300(5)\end{array}$ & 434 & 19 \\
\hline Andes & $\begin{array}{l}22 \text { Sept. (2) } \\
23 \text { Sept. (1) }\end{array}$ & None (4) & $\begin{array}{l}420-430 \\
\text { wounded }\end{array}$ & 335 & 19 \\
\hline $\begin{array}{l}\text { Arthur the } \\
\text { Great }\end{array}$ & $\begin{array}{l}22 \text { Sept. (2) } \\
23 \text { Sept. (1) }\end{array}$ & $2-0 \operatorname{lbs}(3)(4)$ & $\begin{array}{l}384 \text { wounds and } \\
\text { cholera }\end{array}$ & 322 & 45 \\
\hline Orient & $\begin{array}{l}22 \text { Sept. (2) } \\
23 \text { Sept. (1) }\end{array}$ & None (4) & $\begin{array}{l}274 \text { of which } \\
203 \text { wounded }\end{array}$ & 190 British & 33 \\
\hline Colombo & 22 Sept. (2) & $2-0 \operatorname{lbs}(3)(4)$ & No data & $\begin{array}{c}480(2) \\
553 \text { - at least } \\
442 \text { wounded(5) }\end{array}$ & $\begin{array}{r}30 \\
(2)(5)\end{array}$ \\
\hline Caduceus & 24 Sept. (2) & None (4) & 430 , no wounded & 318 & 111 \\
\hline Courier & 25 Sept. (2) & None (4) & $\begin{array}{l}291 \text {, all sick } \\
\text { except one } \\
\text { wounded Russian }\end{array}$ & $\begin{array}{l}265 \\
+ \text { prisoners }\end{array}$ & 33 \\
\hline Timandra & $\begin{array}{l}29 \text { Sept. (1) } \\
30 \text { Sept. (2) }\end{array}$ & None (4) & No data & 305 & 53 \\
\hline Medway & No data & $0-3 \mathrm{oz}(3)$ & No data & No data & \\
\hline Himalaya & No data & $0-4 \mathrm{oz}(3)$ & No data & No data & \\
\hline $\begin{array}{l}\text { Golden } \\
\text { Fleece }\end{array}$ & No data & $0-40 z(3)$ & No data & No data & \\
\hline
\end{tabular}

Sources: (1) Hospitals report, see note 32 above, pp. 193-202.

(2) Medical and surgical history, see note 21 above, pt 2, p. 465.

(3) RAMC 397 FRS 6/3, see note 30 above.

(4) Ibid., FRT 1/1.

(5) The Times, 13 Oct. 1855 , p. 8, col. 3. 


\section{Henry Connor}

anyone knowing where they [were]. In December they were accidentally discovered in the Store in the Light Division, the packages all broken open and the things plundered. ${ }^{62}$

Another reference in Hall's papers gives a slightly different version:

... and the captain of the Andes, feeling indignant at . . having his ship converted into a hospital ship, stowed away the stores that had been put on board at Varna, in the hold of his vessel; and when the ship was required to take the wounded down to Scutari after the battle of the Alma, he declared to the Admiral, that no stores of the kind were on board his ship, and there was no-one present to contradict him, as the Medical Officer had been taken out of the vessel and put on board the Kangaroo and Dunbar at Toulza Bay. Some months afterwards the cases containing these stores were found in a Regimental Baggage warehouse in Balaklava, broken open, and what remained of their contents was handed over to the Apothecary and Purveyor there. ${ }^{63}$

All the 430 officers and soldiers on board the Andes were wounded rather than sick from illnesses, the majority had severe gunshot wounds, and had undergone amputation of the lower limb. Whether those who needed operation during the voyage were given chloroform must remain uncertain but it seems improbable. Neither the Courier nor the Caduceus was issued with chloroform at Balaklava, but all the soldiers on these two ships, except for a Russian prisoner who had had a foot amputated, were sick rather than wounded. ${ }^{64}$ The Vulcan was another of the transports to which chloroform was not supplied. Her surgeon, James Peters, reported that when he went abroad there were "no medicines, none were sent; but on making a demand, I received such as were needed". 65 Whether the medicines contained a supply of chloroform is not documented, but one of the surgeons who came to assist the over-stretched Peters "had to operate several times without chloroform, amputate thighs, his orderly or servant alone assisting him". 66 The Arthur the Great had been supplied with $2 \mathrm{lbs}$ of chloroform, and her senior surgeon, $\mathrm{Dr}$ Arthur Anderson, described the supply of medicines as "sufficient", and the supply of surgical instruments, materials and appliances as "ample". ${ }^{67}$ However, another surgeon reported that "No medicines were on board but those in the ship's chest, and the captain naturally looked with a jealous eye on these being taken, because he saw the number around to consume, and his natural feelings led him to think of his own crew and their probable future necessities". ${ }^{68}$ The evidence of Archibald McNicol, a private in the 55th Regiment who was wounded at the Alma, indicates that there was some chloroform on board but either the supply was insufficient or the surgeons did not always choose to use it: "There were a good many operations on board. They used chloroform in some cases". 69

The Colombo was also issued with $2 \mathrm{lbs}$ of chloroform at Balaklava. According to the evidence of Corporal Andrew Buchanan of the 19th Regiment, who was on board from 22 to 26 September, there were at least thirty amputations during the voyage: "I came down in the Colombo from Alma ... there must have been, I should say, five or six amputations

\footnotetext{
$62 \mathrm{~V}$ Bonham-Carter, Surgeon in the Crimea: the experiences of George Lawson recorded in letters he sent to his family 1854-55, London, Constable, 1968, p. 190.

${ }^{63}$ RAMC 397, FRT 2, see note 30 above.

${ }^{64}$ Hospitals report, op. cit., note 32 above, pp. 200 and 202.

65 Ibid., p. 196.
}

\footnotetext{
66 'Surgery of war', op. cit., note 37 above. p. 197.

${ }^{67}$ Hospitals report, op. cit., note 32 above,

68 'Treatment of the wounded', op. cit., note 57 above, p. 508.

${ }^{69}$ Hospitals report, op. cit., note 32 above, p. 323.
} 


\section{The Use of Chloroform during the Crimean War}

each day on board". ${ }^{70}$ The medical evidence suggests that there may have been even more. The surgeon of HMS Niger, who was seconded to the Colombo wrote:

Fancy about 650 wounded officers and men, including the Russians, on board our ship, and only three doctors to attend them, myself and two others! I assure you we were working day and night, not even time to sit down to dinner. Nothing but cutting off arms and legs all day long. I had more operations during that time than any London surgeon in a twelvemonth. We could not operate fast enough to save all the wounded on board. I had one amputation of the shoulder-joint, and as for thighs and legs, I left off counting them. ${ }^{71}$

A secondhand report added, "I have it from the lips of a senior officer on board the Colombo, with whom I am upon most intimate terms, that they alone had 600 wounded on board, and during the whole passage ... that the three surgeons never ceased their amputations, assisted by volunteers from the crew of the ship; that the decks were running with blood the whole time worse than shambles, and the exhalations were overpowering in the extreme". ${ }^{72}$ Two pounds of chloroform can scarcely have been sufficient for the number of operations during the voyage. Hall, commenting on the provision of the transport ships, wrote that "All these ships had to be separately fitted up for sick and wounded from our necessarily limitted [sic] stores at Balaklava . ..."73

\section{Availability and Use of Chloroform at Balaklava and Inkerman}

Calculation of the availability of chloroform at regimental level at the battles of Balaklava and Inkerman is uncertain because there is little or no information about regimental stocks at these times. Those regiments which were heavily involved at the Alma had almost certainly exhausted their supplies following that battle. Medical Officers from regiments which were not involved went to the assistance of those who were ${ }^{74}$ and must therefore have used some of their regimental supplies as well. W G Watt, the surgeon to the 23rd Royal Welch Fusiliers, was unable to obtain chloroform from either the divisional store (Light Division) or from the General Hospital at Balaklava after the battle of the Alma, ${ }^{75}$ which would imply that these sources had not been able to obtain any from the Dispenser's stores in Balaklava. The Dispenser's stocks must have been low on 2 October because on that date the Light Division put in a requisition for $8 \mathrm{lbs}$, but received only $4 \mathrm{lbs}$ three days later. ${ }^{76}$ Subsequent requisitions from the Light Division on 19 October, 8 and 22 November, and 9 and 13 December did not mention chloroform, so presumably the Division eventually obtained supplies. ${ }^{77}$

On 15 October Mr J E Kersey, the Dispenser of Medicines in charge at Balaklava, put in a request to Scutari for $40 \mathrm{lbs}$ of chloroform, but received only $15 \mathrm{lbs}$ and that not until 29 October, ${ }^{78}$ which was four days after the battle of Balaklava. The implication must be that stocks of chloroform in the Crimea were low at the time of that battle. Whether they

\footnotetext{
70 Ibid., p. 312.

71 Anon., 'The war', Lancet, 1854, ii: 388-9, p. 389.

${ }^{72}$ Anon., 'Treatment of the wounded', Lancet, 1854, ii: 495 .

${ }^{73}$ RAMC 397, FRT 2, see note 30 above.
}

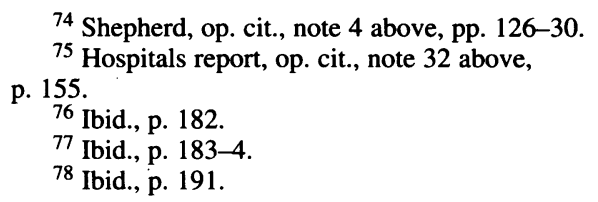




\section{Henry Connor}

had been replenished before the battle of Inkerman cannot be determined from the surviving records. Certainly Kersey did not include chloroform among his requirements in his requisition in November, ${ }^{79}$ and nor did his deputy, Mr F Fernandez, mention it in his list of items "required most urgently for the use of Lord Raglan's army in the Crimea" on 16 December $1854 .^{80}$ The Field Hospital of the 20th Regiment was able to obtain in full a small requisition for $4 \mathrm{oz}$ of chloroform on 1 December $1854,{ }^{81}$ but whether this was obtained from the Divisional Store or from Dispenser Kersey in Balaklava is not stated. No fresh supplies of chloroform arrived in Turkey or the Crimea between 4 September 1854 and 19 January 1855 , but Fernandez recorded that $16 \mathrm{lbs}$ was "on hand in store" at Balaklava on 1 January $1855 .{ }^{82}$ It is possible that the balance of the October requisition had arrived following the interim supply of $15 \mathrm{lbs}$ which Kersey received on 29 October, and that is why neither Kersey or Fernandez made any mention of chloroform in their requisitions in November or December. It is also possible that they were not always fully aware of the total amount of chloroform in their possession during October, November and the first half of December. As Kersey explained to the Commissioners who were sent to investigate the state of the hospitals in the Crimea and Scutari:

I had my supplies at first on board the John Masterman [a store ship in Balaklava harbour]. They were not landed until December 18th. I had great difficulty in finding what I wanted. I had constantly to dive down into the hold of the ship; and as the crew occasionally shifted my cases, I had great difficulty in putting my hand on them ... The Purveyor had his stores on board the John Masterman as well as me, and our stores got intermixed and great confusion arose. I have had great delay in getting things landed. I also had great difficulty in complying with requisitions as long as the stores remained on board the John Masterman, as I had to go on board on all occasions, and I could not always obtain a boat. ${ }^{83}$

His deputy, Mr Fernandez, gave a similar description of their difficulties. ${ }^{84}$ Their problems must have been aggravated when the John Masterman was badly damaged in the great storm on 14 November $1854 .{ }^{85}$

There are only a few surviving documents and reports which mention the availability and use of chloroform following the battles of Balaklava and Inkerman. The official medical history of the war claimed that "On the field at Alma, it [chloroform] was largely employed, and still more generally at Balaklava and Inkermann . . .86 However, this report has to be treated with some caution as the authors were anxious to rebut the criticisms which had been made as a result of Hall's caution against the use of chloroform in gunshot wounds. A report from an anonymous, probably regimental, surgeon, written after the battle of Inkerman stated that "we had plenty of water, brandy, opium, beef-tea and chloroform, hay, blankets, etc., . . . Chloroform was generally used-in this regiment in every serious operation". ${ }^{87}$ The same journal published another letter which said "we had lots of water, brandy, opium, blankets, hay, chloroform . ..", 88 which may have been

79 Ibid., p. 190.

80 Ibid., p. 191.

81 Ibid., p. 106.

82 RAMC 397, FRS $2 / 1$ and FBS $1 / 5$, see note 30 above.

${ }^{83}$ Hospitals report, op. cit., note 32 above, p. 334.

84 Ibid., pp. 336-7.
85 Hall Diaries transcript, RAMC 524/15/6.

${ }^{86}$ Medical and surgical history, op. cit., see note 21 above, pt 2, p. 266.

87 Anon., 'Use of chloroform at Inkermann', Med. Times Gaz., 1854, ii: 671 .

${ }^{88}$ Anon., 'Medical life in camp', Med. Times Gaz., 1855, i: $47-8,48$. 


\section{The Use of Chloroform during the Crimean War}

written by the same surgeon as the author stated that he had written a previous letter, and the items mentioned as being plentiful are so similar. Shepherd suggests that the author was Assistant-Surgeon John Wyatt of the Coldstream Guards who also noted in his regimental report that "Chloroform, with two exceptions, was employed in every case". 89 However, E M Wrench, who arrived in the Crimea a few days after the great storm of 14 November 1854 , commented that

The older surgeons had a great dread of (the then recently invented) chloroform, fostered by the historical memorandum from the Director-General almost forbidding its use ... We therefore only used chloroform for the more serious operations, and never to facilitate examination, or for what we consider trivial operations, as cutting out bullets or setting compound fractures. ${ }^{90}$

After the battles of Balaklava and Inkerman the more seriously injured were again transferred to Scutari. In comparison with the critical reports of the transfer of those wounded at the Alma, there appears to have been' relatively little complaint about conditions on the transport ships after these later battles. Information about supplies of chloroform on the transports at this time is shown in Table 6. The Talavera and the Andes carried, between them, about 400 wounded but no chloroform. Assuming an amputation rate of 5 per cent among the wounded and $2 \mathrm{oz}$ of chloroform for each anaesthetic, ${ }^{91}$ then the supplies of chloroform on the remaining ships were probably adequate, especially as it is likely that some of the wounded had had their operations before embarking.

Hall and his staff were still experiencing difficulties in equipping the transport ships in December 1854 and January 1855. In a letter to the Quartermaster General written on 18 January $1855,{ }^{92}$ in response to a complaint about a lack of medical supplies on the Joseph Sheppard, which had sailed from Balaklava on 12 December, ${ }^{93}$ Hall wrote: "So long as . numerous transports have to be fitted up at a few hours notice for the reception of the sick, from limited stores, articles will occasionally run short, or be altogether wanting, but every effort is made to obviate this as much as possible". In the circumstances, it is probably not surprising that some ships sailed with no chloroform on board.

The supplies of chloroform listed in Tables 5 and 6 for ships sailing between 22-30 September, and 26 October and 11 November, after the major battles, total $7 \mathrm{lbs} 5 \mathrm{oz}$. This accords reasonably well with the total of $11 \mathrm{lbs} 1 \mathrm{oz}$ which Dispenser Kersey issued to the "hospital ships" from the store in Balaklava from the end of October to 31 December 1854. 94

\section{The Availability and Use of Chloroform in the Hospitals at Scutari}

By mid-August 1854, $180 \mathrm{lbs}$ of chloroform had been shipped to Turkey and Bulgaria, and it is known that $110 \mathrm{lbs}$ were at Varna on 17 August. ${ }^{95}$ There was a small hospital at

\footnotetext{
${ }^{89}$ Shepherd, op. cit., note 4 above., pp. $234-6$, p. 234.

${ }^{90} \mathrm{E} \mathrm{M}$ Wrench, 'The lessons of the Crimean war', Br. med. J., 1899, ii: 205-8, p. 207.

91 RAMC 397, FRM 1/1-7 and FRM 7/10, see note 30 above; Shepherd, op. cit., note 4 above, p. 132.
} 
Henry Connor

Table 6

Transport ships carrying sick and wounded from the Crimea between 26 October and 11 November 1854

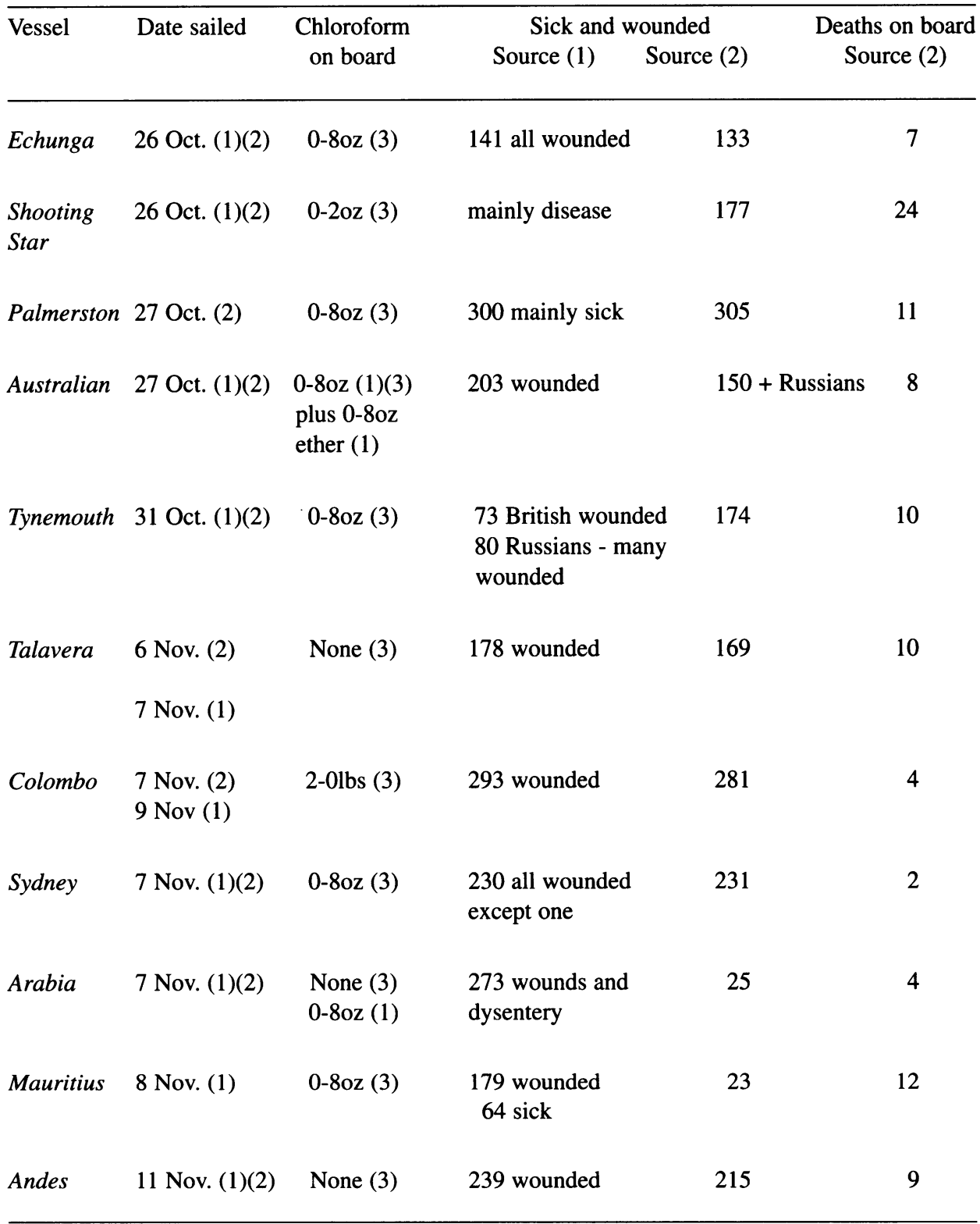

Sources: (1) Hospitals report, see note 32 above, pp. 206-20.

(2) Medical and surgical history, see note 21 above, pt 2, p. 466.

(3) RAMC 397 FRT 1/1, see note 30 above. 
Gallipoli which had $8 \mathrm{oz}$ in store on 1 September $^{96}$ and which did not receive any further supplies in the next three months. ${ }^{97}$ In late August the only other British military base was at Scutari, so it is probable that the remaining $69 \mathrm{lbs} 8 \mathrm{oz}$ of chloroform were in store at the General Hospital there. The Medway, carrying $60 \mathrm{lbs}$ of chloroform, transferred $30 \mathrm{lbs}$ to the John Masterman store ship in Balaklava harbour on 2 September, ${ }^{98}$ and arrived in Varna on 4 September. The remaining $30 \mathrm{lbs}$ was then probably transferred, with the other hospital stores at Varna, to Scutari but not until after 20 October. ${ }^{99}$ At the time of the battle of the Alma the stock of chloroform at Scutari was therefore probably $69 \mathrm{lbs} 8 \mathrm{oz}$. As previously discussed, at least $19 \mathrm{lbs}$ and possibly as much as $44 \mathrm{lbs}$ was subsequently shipped to the Crimea to meet the requisitions of the Dispenser in Balaklava during October to December 1854 , leaving a minimum of $25 \mathrm{lbs} 8 \mathrm{oz}$ available at Scutari until further supplies arrived on 19 January 1855 . At a rate of $2 \mathrm{oz}$ for each anaesthetic ${ }^{100}$ this would have been sufficient for about 200 operations, which should have been more than adequate for the requirements in Scutari at that time. All amputations at Scutari would have been delayed, secondary, operations. During the period from 26 September to 27 November, which covered the major battles of Alma, Balaklava and Inkerman and the first bombardment of Sebastopol, there were either sixty ${ }^{101}$ or sixty-five ${ }^{102}$ secondary amputations. The few reports which describe the use of chloroform at Scutari confirm that supplies were adequate. The Reverend Sydney Osborne was appointed Almoner to The Times Fund and arrived in Constantinople on 8 November, three days after the battle of Inkerman. He went on to Scutari almost immediately and stayed for four or five weeks. During his time there "chloroform was always used ...", even though "there was not a single operating table". ${ }^{103}$ George Pyemont Smith, who arrived at Scutari on about 17 November and stayed until at least 18 February, commented that "an operation was never commenced before the patient was fully under the influence of chloroform". ${ }^{104}$ The evidence of Osborne and Pyemont Smith shows that supplies of chloroform were adequate between early November 1854 and mid-February 1855. In fact by early February the supplies were more than adequate, amounting to $186 \mathrm{lbs}$ $8 \mathrm{oz}$; of which $82 \mathrm{lbs}$ were in the General Hospital store, $4 \mathrm{lbs} 8 \mathrm{oz}$ in the Barrack Hospital store, and a further $100 \mathrm{lbs}$ were as yet unpacked. ${ }^{105}$ The unpacked stocks had probably come with the Army and Navy and the Eagle, both of which arrived in the East on 19 January, the former carrying $100 \mathrm{lbs}$ and the latter $50 \mathrm{lbs}$.

\section{The Availability and Use of Chloroform from January 1855 until the End of the War}

The severity of the Crimean winter limited the potential for military activity during the first three months of 1855 and, although the troops suffered severely from the effects of poor sanitation, disease and malnutrition, there were only 39 amputations among patients admitted to the army hospitals during this quarter (Table 7). Nearly 60 per cent of these

\footnotetext{
${ }^{96}$ Hospitals Report, op. cit., note 32 above, p. 298.

97 Ibid., p. 289.

98 Ibid., p. 58.

99 Hall Diaries transcript, RAMC 524/15/6.

100 Shepherd, op., cit., note 4 above, p. 132.

${ }^{101}$ RAMC 397, FRM 2/8, see note 30 above.
}

\footnotetext{
102 Medical and surgical history, op. cit., note 21 above, pt 2, p. 373.

${ }^{103}$ S G Osborne, Scutari and its hospitals, London, Dickinson Bros., 1855, pp. 19-20.

104 Pyemont Smith, op. cit., note 25 above, p. 648.

105 Hospitals Report, op. cit., see note 32 above, p. 350 .
} 


\section{Henry Connor}

Table 7

Numbers and amputations, and the percentages in which chloroform was used, from 19 September 1854 to 31 December 1855

\begin{tabular}{lcccc}
\hline Date & \multicolumn{2}{c}{ All amputations } & \multicolumn{2}{c}{ Excluding fingers and toes } \\
\hline & Total & $\begin{array}{c}\text { \% in which } \\
\text { chloroform used }\end{array}$ & Total & $\begin{array}{c}\text { \% in which } \\
\text { chloroform used }\end{array}$ \\
\hline 19 Sept. to 31 Dec. 1854 & 222 & 60 & 160 & 66 \\
1 Jan. to 31 March 1855 & 39 & 95 & 16 & 100 \\
1 April to 30 June 1855 & 337 & 72 & 203 & 89 \\
1 July to 30 Sept. 1855 & 637 & 60 & 402 & 75 \\
1 Oct. to 31 Dec. 1855 & 118 & 64 & 94 & 66 \\
\hline
\end{tabular}

Source: Quarterly returns of wounds and injuries received in action admitted into the hospitals of the army in the East, RAMC 397 FRM 1/1 to 1/6, see note 30 above.

operations were on fingers and toes, probably as a consequence of frost-bite. Although the majority of amputations at this time were minor ones, chloroform was used in all except two cases, whereas it had been used in only 60 per cent of cases in the first few months of the war. The increased use of chloroform may have been a consequence of the relatively small number of cases requiring amputation. The requirement for supplies of chloroform would have been proportionately lower than it had been following the major battles of the Alma, Balaklava, and Inkerman, and the first bombardment of Sebastopol. Moreover, the surgeons would not have been overwhelmed by large numbers of patients who required urgent surgery. The Association Medical Journal had been critical of Hall's "caution" against the use of chloroform, but recognized that

Chloroform when applied properly causes a delay of three or four minutes before the commencement of the operation, and it requires one extra hand during the whole time of its performance. To put a patient only partially under the influence of chloroform is worse than useless, as it renders the operation more difficult for the surgeon; and to have the patient recovering before the end of the operation is equally embarrassing. On these accounts an extra person is required for its management, and this person could probably not be spared during a great battle. But great battles only occur now and then, and warfare is chiefly made up of petty skirmishes and prolonged sieges, for the constantly recurring casualties of which there is usually a sufficient staff of surgeons in attendance. ${ }^{106}$

The difficulties of using chloroform in the field at the time of a great battle were described by an artillery surgeon who was present at Inkerman:

106 'Chloroform on the battlefield', op. cit., note

16 above, p. 1029. 


\section{The Use of Chloroform during the Crimean War}

I hear there is a great cry against our not using chloroform; but, the more I see, the more strongly am I convinced that it is not of much value in the field; it reduces the number of medical men available for duty. It would be simply murder to leave the administration to any but educated hands, and seldom can you get more than one doctor to assist at an operation; for instance, I had to amputate a leg and an arm, with only my own servant as an assistant; and how many others have had to operate under even more unfavourable circumstances, I cannot say, but they were many. . . . Operating in the field and in a well-found Hospital are vastly different affairs. ${ }^{107}$

The relatively small number of patients requiring amputations between January and March 1855 would have placed little strain on the surgeons and there would have been spare hands available to give the anaesthetic. Supplies of chloroform were clearly adequate to meet the small demand. It is also possible that the outcry at home encouraged the surgeons to use chloroform more readily.

After the bombardment of Sebastopol was restarted on 9 April 1855 the casualty rate increased substantially, and there were 337 amputations during April, May and June. Chloroform was used in only 72 per cent of these operations. Further supplies arrived during these months but it is possible that, once again, the chloroform was not always available when and where it was needed. On 5 February there were $186 \mathrm{lbs} 8 \mathrm{oz}$ at Scutari ${ }^{108}$ and very little of this can have been used during February and March. However, on 13 April Dr Andrew Smith, the Director General of the Army Medical Service in London, wrote to Hall in the Crimea to express his concern about the total lack of quinine and the small stocks of chloroform available at Balaklava on 5 March:

I earnestly request you will take care to prevent your stock of medicines getting so low as it appears to have been on the 5th ultimo, as under the present circumstances of the troops a much larger supply ought always to be available for issue, and I cannot believe it possible that any difficulty can exist in maintaining such a supply, as the quantities of every article at Scutari must be very large.

The total want of quinine and the small amount of chloroform which you return in store especially attracted my attention, and care must be taken to avoid the necessity of having to make such confessions in future. You may rest assured the public will not lose this opportunity of holding up the department to further obloquy; but even were there no reason to fear that, it must be kept in mind that nothing but the absolute inability of securing the articles could warrant such a want of them. ${ }^{109}$

By the end of March 1855 the stocks of chloroform at Balaklava amounted to $41 \mathrm{lbs} 6$ oz and on 27 April Smith wrote again to Hall to express his

... great satisfaction ... that the medical supplies are now abundant, and I trust that there will never again be any deficiency, either in regimental hospitals or the divisional, or in the central store attached to the army, but that an arrangement shall be made, and strictly carried out, whereby medical stores far in advance of any possible demand shall be forwarded on your requisition from the medical depôt at Scutari, at which station a superabundance will always be found. ${ }^{110}$

Smith must have hoped that the adverse publicity resulting from a lack of medical supplies would now be a thing of the past, but barely more than two weeks later he had to deal with a complaint that there was now a "total lack of quinine in the camp hospitals in

107 Anon., 'Medical life in camp', Med. Times Gaz., 1854, ii: $603-4$, p. 604.

108 Hospitals report, op. cit., note 32 above, p. 350 .

\footnotetext{
109 Sanitary report, op. cit., note 40 above, p. 47, Letter No. 160.

${ }^{110}$ Ibid., p. 51, Letter No. 183.
} 


\section{Henry Connor}

the East". 111 In this letter Smith also commented on the work of Mr Fernandez who was by then the Chief Apothecary in charge of the medical stores at Balaklava:

I observe you mention that Mr Apothecary Fernandez has occasionally permitted the quantity of certain articles in the medical store under his charge to get low, without making you acquainted with the circumstance. You must administer him a warning against such a practice and order him to report to you in writing, at least twice a week, to the condition of the medical depôt as to the quantity and quality of the stores in his charge.

Should Mr Fernandez again prove inattentive, you will not hesitate at once to prefèr charges against him for neglect of duty, and will take care to press the utmost rigour of martial law against $\operatorname{him} . .$.

One has to feel-sympathy for poor Fernandez because, at about the same time that he would have received his severe warning for allowing the stocks to run too low, Hall received another letter from Dr Alexander Cumming, the Principal Medical Officer at Scutari, complaining that "Mr Fernandez makes enormous demands ...",12 and again, on 12 June, "Dr [sic] Fernandez requisitions astonished Mr Joseph and really they are enormous". ${ }^{113}$ Even so, the stocks of chloroform in the store at Balaklava had fallen to 18 lbs $8 \mathrm{oz}$ by 30 June as Fernandez was regularly issuing more than he was receiving from Scutari. ${ }^{114}$ The complaint about the lack of quinine, which had led to this latest round of correspondence, was investigated. At the time at which the complaint was made there were indeed no stocks in the Balaklava store. There were, however, $28 \mathrm{lbs}$ to be found among the Regimental Hospitals but the distribution was uneven and some regiments and divisions had no quinine at all. ${ }^{115}$ It is possible that shortages of chloroform may have arisen as a result of similar inequalities in distribution. The shortage of quinine may have resulted from the practice, started in the 1st Division, of issuing quinine prophylactically for the prevention of fever. ${ }^{116}$ Smith approved of this and sent further large supplies to meet the increased demand. ${ }^{117}$

During July, August and September deliveries of chloroform to the stores in Balaklava amounted to $500 \mathrm{lbs} .{ }^{118}$ How much of this had been received before the assault on the Redan on 8 September 1855 , when the British suffered very heavy casualties, cannot be determined from the surviving records. A large shipment of $208 \mathrm{lbs}$ of chloroform arrived in the East on 29 August, just nine days before the storming of the Redan. If it had been unloaded in Balaklava it would have been available in time for the battle, but if it had been shipped to Scutari it might not have been transferred to Balaklava in time. Two pieces of evidence suggest that it was unloaded in Scutari. All supplies were supposed to be delivered to Scutari; stocks were then sent to Balaklava as and when requisitions from there were received. However, Smith in London had been sending some medical supplies directly to Balaklava "in consequence of Dr Hall having repeatedly complained of the difficulties he has experienced in obtaining supplies from Scutari ...”, and on 2 July 1855

111 Ibid., p. 54, Letter No. 196.

$112 \mathrm{~J} \mathrm{~W}$ Warburton, 'A medical history of the British expeditionary force in the east 1854-1856', PhD thesis, University of Keele, 1982, Appendix I, 'Transcript of letters written by Inspector General Cumming, PMO Scutari, to Inspector General Hall, PMO to the Expeditionary Force', p. 192.
113 Ibid., p. 195.

114 RAMC 397, FRS 2/2, see note 30 above.

115 Sanitary report, op. cit., note 40 above, pp. 55,

62, Letters Nos. 200, 232, 234.

116 Ibid., p. 63, Letter No. 235.

117 Ibid., p. 55, Letter No. 200.

${ }^{118}$ RAMC 397, FRS 2/3, see note 30 above. 
Smith had had to explain his unauthorized actions to the Deputy Secretary at War. ${ }^{119}$ In the light of this experience, he would probably have reverted to sending supplies in the authorized manner to Scutari. The fact that the Balaklava stores issued only $46 \mathrm{lbs} 7 \mathrm{ozs}$ of chloroform during July, August and September ${ }^{120}$ also suggests that the majority of the $500 \mathrm{lbs}$ received during this time did not arrive until after the major action on 9 September. No reports of shortages of chloroform have survived from this period, but anaesthesia was used in only 60 per cent of the 637 amputations which took place between 1 July and 30 September. How far this was the result of shortages, or of lack of spare personnel to give anaesthetics, or of medical practice and opinion, cannot be determined.

After the Russians evacuated Sebastopol in early September minor skirmishes continued, and there were 118 amputations during the final quarter of 1855 . There can have been no shortages of chloroform at this time, either in the Crimea or in Scutari. The stores in Balaklava had $472 \mathrm{lbs}$ in stock on 1 October, and during the next three months only $59 \mathrm{lbs}$ were issued. ${ }^{121}$ At Scutari there were $699 \mathrm{lbs} 8 \mathrm{oz}$ in stock on 1 March $1856 .{ }^{122}$ The only supply to reach the East between 1 October 1855 and 1 March 1856 was a shipment of $450 \mathrm{lbs}$ which arrived on 19 January. There must therefore have been in excess of $250 \mathrm{lbs}$ available at Scutari on 1 October 1855. Despite this abundance, and the relatively small number of amputations during the last quarter of the year, only 64 per cent of patients were given anaesthetics. Only one conclusion is possible. At the end of the Crimean War surgeons were choosing to use chloroform in only two-thirds of patients who required amputation. This proportion is identical to that at the beginning of the war when chloroform was undoubtedly in short supply and when some surgeons were particularly likely to have been influenced by Hall's "caution".

\section{The Validity of the Data in Table 7}

The discussion and conclusions in the previous sections depend heavily on the validity of the data in Table 7, which is derived from statistical returns in the private papers of John Hall. The information on amputations in these statistical returns differs from that given elsewhere in the Hall papers (Table 8), and from that given in the official medical history of the war, ${ }^{123}$ in several respects. First, the data given in the official history are limited to the period from 1 April 1855 to "the end of the war", apparently on the grounds that reliable information on the numbers of amputations before April 1855 was not available. Even when allowance is made for this (source 2 in Table 8) there is a considerable discrepancy. All sources in the Hall papers give numbers of amputations which are greater than those in the official history. It could be that some of the returns in the Hall papers are an overestimate, perhaps as a result of counting the same patients twice if they were initially admitted to a Field or Regimental Hospital and then transferred to a General Hospital. However, the data for Field Hospitals alone in the Hall papers (sources 5 and 6 in Table 8) give numbers which are higher than those in the official history, and it is improbable that there is duplicate counting in these figures because a Field Hospital would

\footnotetext{
119 Sanitary report, op. cit., note 40 above, Letter No. 259.

${ }^{120}$ RAMC 397, FRS 2/3, see note 30 above.

121 Ibid., FRS 2/4.
} 


\section{Henry Connor}

Table 8

Information on numbers of amputations during the Crimean War

\begin{tabular}{|c|c|c|c|}
\hline Source & Site of operation & Period covered & $\begin{array}{l}\text { Number of } \\
\text { amputations }\end{array}$ \\
\hline 1. RAMC 397 FRM 1/1-1/6 & "Admitted into hospitals" & Entire war & 1353 \\
\hline 2. Ibid. & ditto & $\begin{array}{l}1 \text { April } 1855 \text { to } \\
31 \text { Dec. } 1855\end{array}$ & 1092 \\
\hline 3. RAMC 397 FRT 2 & Field Hospitals and Scutari & ? Entire war & 1134 \\
\hline 4. RAMC 397 M1/17 & Hospitals & Entire war & 1134 \\
\hline 5. RAMC 397 FRM $1 / 7 \mathrm{~b}$ & Field Hospitals & Entire war & 925 \\
\hline 6. RAMC 397 FRT 2 & Field Hospitals & Entire war & 984 \\
\hline 7. RAMC 397 FRM 2/8 & $\begin{array}{l}\text { Hospitals "General and } \\
\text { Supplementary" }\end{array}$ & $\begin{array}{l}26 \text { Sept. } 1854 \text { to } \\
27 \text { Nov. } 1854\end{array}$ & 211 \\
\hline $\begin{array}{l}\text { 8. Med. surg. hist., } \\
\text { pp. 363-79 }\end{array}$ & All cases & $\begin{array}{l}1 \text { April } 1855 \text { to } \\
\text { end of war }\end{array}$ & 777 \\
\hline 9. Med. surg. hist., p. 339 & All cases & ditto & 811 \\
\hline 10. None found & Transport ships & & unknown \\
\hline
\end{tabular}

Sources: RAMC 397, see note 30 above. Medical and surgical history, see note 21 above.

only note the initial hospital admission. The various numbers given in sources from the Hall papers are probably consistent with one another. If there were approximately 950 amputations in Field Hospitals, then a total of 1134 in all hospitals (sources 3 and 4 in Table 8) would be appropriate. The figures given in sources 3 to 6 are for operations "in hospitals", whereas the numbers in source 1 are for patients "admitted into hospitals" and probably, therefore, include those whose operations were performed on the transport ships between Balaklava and Scutari. There is no quantitative information about the numbers of amputations carried out on the transports, but the anecdotal evidence cited earlier would suggest that there were many. It is not clear why the statistical returns in the Hall papers do not appear to have been available to the authors of the official report, although one might speculate that the information about the large proportion of cases in which chloroform was not used could have caused considerable embarrassment. 


\section{The Use of Chloroform during the Crimean War}

\section{Medical Opinion at the End of the War}

Two important sources of opinion at the end of the war are the reports of meetings of the Crimean Medical and Surgical Society ${ }^{124}$ and the official medical history of the war. ${ }^{125}$ The reports of the Crimean Medical and Surgical Society give opinions of sixteen doctors, but it is not known how many others attended these meetings without expressing an opinion or having it recorded. Some members may have refrained from speaking out if their views conflicted with those of Hall, who chaired three of the four meetings, and who, although he had been heavily criticized during the war, was still a man of considerable influence within the Army Medical Service. The authors of the official history were determined to counter the allegations of brutality which had been levelled against the Army Medical Service in general as a result of Hall's original "caution" against the use of chloroform. In doing so, they may have over-emphasized the opinions of those who favoured the liberal use of anaesthesia. If the use of chloroform at the end of the war had fallen to the same level that it had been at the start was this because, despite its being readily available, surgeons had developed increasing doubts about its value or safety? It is evident that there was still a significant minority of surgeons who were reluctant to use anaesthesia, and they gave various reasons to substantiate their practice.

It was still argued that civilian experience was irrelevant to military practice, which differed in several important respects. For example, Mouat referred to the peaks in workload which followed a military engagement, pointing out, as had been argued at the start of the war, ${ }^{126}$ that in these circumstances the extra time required for anaesthetization and recovery, made it impossible to use chloroform in every case. ${ }^{127}$ Mouat still considered that gunshot wounds were different from the wounds suffered in civilian practice, and that the shock associated with such wounds was likely to be aggravated by chloroform. In this context it must be remembered that, to the surgeons of the time, the term "shock" implied something more than just hypovolaemia due to blood loss. Shock, to the military surgeon

is of a compound nature, in the composition of which the following elements may often be recognized:

1. The vital effects following all severe injuries.

2. The mechanical effects, probably many and various, of the peculiar velocity and momentum of the impinging force, especially in reference to cannonshot injuries.

3. Probably, additional vital effects of the above-mentioned velocity and momentum.

4. Nervous depression, consequent on previous high nervous tension.

5. Loss of blood to a considerable extent, sometimes by a large quantity suddenly effused; sometimes by a longer process of gradual drain.

\footnotetext{
124 Reports of Crimean Medical and Surgical Society, op. cit., notes 19, 28 and 46 above.

125 Medical and surgical history, op. cit., note 21 above, pt 2, pp. 266-72.
}

\footnotetext{
126 'Chloroform on the battlefield', op. cit., note 16 above.

${ }^{127}$ Report of Crimean Medical and Surgical Society meeting, op. cit., note 28, above, p. 253.
} 


\section{Henry Connor}

Practically we find that many never 'rally', to use a technical and often misapplied word, from this state; and a large number of patients died in it. No physical cause can be assigned for these deaths. Often a very minute quantity of blood had been lost . . ${ }^{128}$

It is in this context that Hall's original caution against the use of chloroform ${ }^{129}$ must be considered. Hall, and many other military surgeons, believed that the shock which followed injury due to gunshot and cannon wounds was different in character from that which occurred in civilian injuries. Military surgeons also believed that "chloroform is a powerful depressant of vital action", ${ }^{130}$ which made it more likely that many patients would never rally from the type of shock which characterized gunshot injuries. Hall's opinion remained unchanged throughout the war. Commenting on a case where chloroform was thought to be the undoubted cause of death, Hall wrote on 14 March 1856:

This was one out of many untoward accidents that have occurred from the use of chloroform during the war. It proved more immediately fatal, and so attracted special attention; but if the cases where men never rallied, and died within a few hours after its exhibition, were as accurately detailed, the list would be a long one. But as I have already incurred much public odium for a wellintentioned, but carelessly worded caution, I am not going to re-open the question, only I feel authorised in saying that I have seen much to confirm the propriety of that caution, and all candid and unprejudiced men, I rather think, will admit the same. ${ }^{131}$

Mouat seems to have concurred with Hall's opinions in every respect when he addressed the Crimean Medical and Surgical Society. He concluded: "1. That there are states of shock . . . in which chloroform may destroy life in various ways. 2 . There are likewise cases in which, as I have stated, the patient never fairly rallies, but sinks gradually without any effort at reaction; these cases are never returned as deaths from chloroform."132

In the discussion which followed Mouat's paper, ${ }^{133}$ Dr Gordon concurred with Mouat's views, and a similar opinion was expressed by an anonymous doctor quoted in the official medical history of the war: "My own impression, from what I have seen of the effects of the drug, is that many of these cases died from the exhaustion induced by the shock of the injury and the consequent operation, but that this exhaustion was assisted and kept up in a most material degree by the depressing influence of the chloroform". ${ }^{134}$

However, of the sixteen doctors who attended and spoke at meetings of the Crimean Medical and Surgical Society, ${ }^{135}$ only four (Hall, Mouat, Gordon and Wyatt) believed that chloroform impaired the patient's ability to rally. Of the remaining twelve, ten were generally in favour of chloroform and three (Macleod, Bone and George Blenkins) specifically expressed the view that it actually minimized the effects of shock, improving survival and enabling some operations which could not otherwise have been undertaken. Similar opinions were voiced by others. J H McCowan described an amputation through the neck of the femur which "could not have been performed without an anaesthetic, with

\footnotetext{
${ }^{128}$ Medical and surgical history, op. cit., note 21 above, pt 2, pp. 265-6.

129 Longmore Papers, RAMC 1139, LP 9/11, see note 10 above.

${ }^{130}$ The Times, 13 Oct. 1854 , p. 5, col. 5.

${ }^{131}$ Medical and surgical history, op. cit., note 21 above, pt 2, pp. 268-9.

132 Report of Crimean Medical and Surgical
}

Society meeting, op. cit., note 19 above, p. 227.

133 Reports of Crimean Medical and Surgical Society meetings, op. cit., notes 28 and 46 above.

${ }^{134}$ Medical and surgical history, op. cit., note 21 above, pt 2, p. 267.

135 See reports of Crimean Medical and Surgical Society meetings, op. cit., notes 19,28 and 46 above. 
any prospect of the patient surviving the shock", ${ }^{136}$ and another surgeon, quoted anonymously in the official report, wrote, "I am of the opinion that the greater the shock the more useful is chloroform, and the sooner it can be resorted to the better", provided that "there was a rational hope of life being saved by the operation". ${ }^{137}$ Thomas Alexander recorded the case of a patient, quoted by Guthrie, "who was so low when placed on the table, that brandy-and-water was given to him, and he was then immediately placed under chloroform. When I had finished, it was found that his pulse was stronger than before commencing the operation", ${ }^{138}$ which was for amputation at the shoulder. Such opinions on the "stimulant" effect of anaesthesia had certainly become the orthodox view in the USA by $1861 . .^{139}$

When considering the suggestion that chloroform impaired "rallying", it is relevant that the depth of anaesthesia which was sometimes used in the Crimea was considerable. Pyemont Smith wrote that: "Generally speaking, at Scutari, the patient was, by means of chloroform, brought into the condition of a dead body, and then it was not an operation, but a dissection that was performed", 140 and the Reverend Sydney Osborne described the difficulty in arousing one particular patient whom he had anaesthetized. ${ }^{141}$ Mouat commented that "Everyone who had witnessed the numerous operations at the General Hospital [in camp at Balaklava], must have been struck with the length of time it was often necessary to keep the patients on the table, to enable them to rally from the chloroform insensibility". ${ }^{142}$ In these circumstances it would not be surprising if some patients, weakened not only by their wounds but also often by disease, never recovered from the operations.

Chloroform was almost invariably administered on lint or a napkin, ${ }^{143}$ either because this method was more convenient on the battlefield or because some of the surgeons thought it safer than inhalers. ${ }^{144}$ In 1850 about 30 per cent of army surgeons were Scottish, ${ }^{145}$ and would probably have favoured Simpson's method of administration. ${ }^{146}$ Florence Nightingale provided two "chloroform instruments" at Scutari during November or December, ${ }^{147}$ and inhalers were more generally available, certainly by April 1855 when there were 40 in stock in the Balaklava stores, but only 18 had been issued by the end of

$136 \mathrm{~J} \mathrm{H}$ McCowan, 'An account of the wounded of H.M.'s Fifty-Fifth Regiment', Med. Times Gaz., 1856, i: 205-6, p. 206.

${ }^{137}$ Medical and Surgical History, op. cit., note 21 above, pt 2, p. 267.

${ }^{138}$ Longmore Pamphlets, RAMC 423, vol. 5, Paper 1 , see note 27 above.

139 Ibid., Papers 11 and 12.

140 Pyemont Smith, op. cit., note 25 above, pp. $647-8$, p. 648.

141 Osborne, op. cit., note 103 above, pp. 20-1.

142 Report of Medical and Surgical Society meeting, op. cit., note 28 above, p. 253.

143 Report of Crimean Medical and Surgical Society meeting, op. cit., note 46 above; Osborne, op. cit., note 103 above; and W H Flower, 'Notes on surgical practice in the Crimea', Med. Times Gaz., 1856, i: 308-9.

${ }^{144}$ Macleod, op. cit., note 20 above; report of
Crimean Medical and Surgical Society meeting, op. cit., note 46 above.

145 Shepherd, op. cit., note 4 above, p. 12.

146 Simpson took a considerable personal interest in the medical aspects of the war. He arranged for both civilian and army medical officers to take out supplies of chloroform, and hoped that "you will be able to show them how to use it properly". Dr Dowson of the Guards incurred Simpson's wrath because he neither used, nor paid for, the case of chloroform which Simpson provided. Simpson also took a personal interest in the planning of the prefabricated hospital which was erected at Renkioi. J A Shepherd, Simpson and Syme of Edinburgh, Edinburgh and London, E and S Livingstone, 1969, pp. 116-20.

${ }^{147}$ Hospitals report, op. cit., note 32 above, pp. 33-4. 


\section{Henry Connor}

March $1856,{ }^{148}$ of these only two went to hospitals, the remainder being given to divisions or regiments.

The "more immediately fatal" case to which Hall referred occurred on 25 August 1855 and was described in detail. ${ }^{149}$ The patient required amputation of his index finger and the chloroform, which "was administered with his own consent, as he seemed to dread the operation", was given on lint.

As the anaesthesia became more complete and the operation about to be commenced, it was observed that he did not breathe freely ... The chloroform was immediately removed, but respiration could not be observed; a current of air was admitted and water dashed on the face, and ammonia held to the nostrils, but the pulse had ceased. Artificial respiration was had recourse to, and kept up for a long time, but without effect. The heart's action continued for some time after the pulse failed and respiration ceased.

The death was officially attributed to impurities in the chloroform, a sample of which was analysed some time later in Edinburgh and found to be "totally unfit for use, being in a state of complete decomposition". However, the nature of the incident, occurring in a frightened patient, soon after induction and before the operation began, is typical of the cardiac effects associated with chloroform when given in too great a concentration, as described by Snow. Although the case report stated that the chloroform was given in such a way "as to admit a large quantity of atmospheric air", Snow had realized that "the most fatal error with regard to chloroform has been to suppose that the patient was safe so long as he was supplied with sufficient air for the purposes of respiration; for the truth is, that the more air the patient breathes, the greater is his danger, if the air be over highly charged with the vapour". ${ }^{150}$ The statement in the case report that the "heart's action continued for some time after the pulse had failed" is not, of course, compatible with ventricular fibrillation due to chloroform because it presumably implies that heart sounds were heard after the pulse could no longer be felt. If correct, this could indicate a toxic effect of some chemical other than chloroform. However, it is equally probable that this was a cardiac death due to over-exposure to chloroform, which might have been prevented by the use of one of Snow's inhalers which were already available in the Crimea.

The suggestion that wounds and shock seen in military practice differed in some way from those in civilian practice, as proposed by Hall in his original caution in 1854, and still argued by Mouat in $1856,{ }^{151}$ was rejected by the majority of those who expressed an opinion at the end of the war. The most vocal of these was Macleod, who reiterated his views time and time again, ${ }^{152}$ but he was supported by others. ${ }^{153}$ Macleod also recognized

\footnotetext{
148 RAMC 397, FRS 2/2, 2/3, 2/4 and 2/5a, see note 30 above.

${ }^{149}$ Medical and surgical history, op. cit., note 21 above, pt 2, pp. 268-9.

$150 \mathrm{~J}$ Snow, 'Chloroform in London and Edinburgh', Lancet, 1855, i: 108-9; idem, 'Further remarks on the cause and prevention of death from chloroform', Lancet, 1856, i: 148-50, p. 150. The exact mode of sudden death due to chloroform has remained the subject of debate between experimental physiologists and clinicians; for a recent, detailed review see C Lawrence, 'Experiment and experience
}

in anaesthesia: Alfred Goodman Levy and chloroform death, 1910-1960', in C Lawrence (ed.), Medical theory, surgical practice, London and New York, Routledge, 1992, pp. 263-4.

151 Report of Crimean Medical and Surgical

Society meeting, op. cit., note 19 above.

152 Ibid., op. cit., note 28 above, p. 253 , and note 46 above, p. 377; and Macleod, op. cit., note 20 above, p. 992.

153 Ibid., op. cit., note 46 above, p. 378; and Medical and surgical history, op. cit., note 21 above, pt 2, p. 267. 
that chloroform "has certainly thrown a very great weight into the scale in favour of primary amputation. The fear of renewing the shock, which deterred so many from early operation, is now completely removed". ${ }^{154}$ This confirmation of Snow's prediction in $1847^{155}$ was an important consideration because mortality following primary amputations in Field Hospitals was only 23 per cent, compared with secondary amputations, where the mortality was 59 per cent in Field Hospitals and 64 per cent at Scutari. ${ }^{156}$ It was also recognized that anaesthesia made possible the more lengthy and complex operations such as excisions, ${ }^{157}$ but argument remained about the use of a potentially lethal agent in minor operations. Of six doctors whose opinions are recorded four were against using chloroform for amputations of fingers and two were in favour. ${ }^{158}$ The official medical history concluded that "the majority [of surgeons] believe the use of this anaesthetic agent desirable in all cases, both of severe and slight wounds requiring operations . . that a few partially concur in this view; but object to its use in minor operations . ... ${ }^{159}$ However, the evidence in Table 7 suggests that only a minority used it in minor operations, and it was used in only about two-thirds of major operations. Concern over the use of chloroform for minor operations was not confined to military surgeons; Augustin Prichard in Bristol, ${ }^{160}$ for example, shared this worry, though his arguments were rejected by Snow. ${ }^{161}$

Guthrie, writing in 1861, was of the opinion that chloroform "may be administered in all cases of amputation of the upper extremity and below the knee, and in all minor operations". He was less certain about its use in amputations of the middle and upper parts of the thigh, commenting that "the question whether it should or should not be administered in such cases being undecided". ${ }^{162}$ Amputations at the middle and upper thirds of the thigh certainly carried a higher mortality than lower amputations, ${ }^{163}$ but there does not seem to have been any evidence that this was due to chloroform.

\section{Anaesthesia in the British Navy and in the French and Russian Armies}

The use of chloroform by naval surgeons during the Crimean War has been reviewed by $\mathrm{P}$ A Glew. ${ }^{164}$ No official advice, comparable to Hall's memorandum, was given to naval surgeons, but they were instructed that chloroform should be available when the ship was cleared for action, and all ships were provided with twice the usual quantity. Even so, the stocks proved inadequate.

154 G H B Macleod, 'Surgery of the Crimean War', Edinb. med. J., 1856, 1: 1063-87, esp. pp. 1081 and 1086.

155 Snow, op. cit., note 1 above.

156 RAMC 397, FRM 1/7b, see note 30 above.

157 Report of Crimean Medical and Surgical

Society meeting, op. cit., note 28 above, p. 253.

158 Reports of Crimean Medical and Surgical Society meetings, op. cit., notes 28 and 46 above; also Medical and surgical history, op. cit., note 21 above, pt 2, pp. 266 and 272.

\footnotetext{
${ }^{159}$ Medical and surgical history, op. cit., note 21 above, pt. 2, p. 272.

160 A Prichard, 'Death from chloroform', Br. med. J., 1858, i: 207-8.

161 J Snow, 'Death from chloroform', Br. med. J., 1858, i: 279.

162 Longmore Pamphlets, RAMC 423, Paper 11.

163 RAMC 397, FRM 1/7b, see note 30 above.

164 P A Glew, 'Anaesthesia and the Royal Navy 1847 to 1856', History of Anaesthesia Society Proc., 1991, 10: 22-32.
} 


\section{Henry Connor}

In the early part of the war French military surgeons appear to have shared the reservations of some of their British colleagues regarding the use of chloroform. For example, Macleod commented that "the French, too, seemed shy of it, and I have heard some of them hint at its being a fruitful source of secondary haemorrhage"; 165 and William Flower wrote that "the French surgeons seemed also to have entertained a dislike to the use of chloroform at the commencement of the war; for I observed it was very rarely given by them in the operations after the battle of the Alma. Whether further experience has led them to modify their views on the subject, I have not been able to ascertain" ${ }^{166}$ However, in the base hospital of Dolmar-Bagtche in Constantinople, Professor Mounier claimed that chloroform was used in all the cases brought there from the battles of Alma and Inkerman, ${ }^{167}$ just as it was in the British base hospitals in Scutari. ${ }^{168}$ Whether chloroform was used invariably in all the French base hospitals is uncertain, but Macleod, writing six years after the end of the war, commented that "although the French used it very extensively . . . still I do not think, from what I saw of its employment in their hospitals, that they had our confidence in it". ${ }^{169}$ Despite Macleod's comments, the French usage was very considerable, for Macleod quotes a French calculation to the effect that during the Eastern campaign chloroform was employed in 30,000 cases or more, of which 20,000 were in the Crimea itself. Thirty thousand cases would, at a rate of 2 ounces per case, ${ }^{170}$ require $3750 \mathrm{lbs}$ of chloroform; by comparison it can be calculated, from the dates on shipments and stocks of chloroform quoted earlier in this paper, that the British used, at most, only $536 \mathrm{lbs}$. However, the French suffered many more casualties than did the British; there were 4698 amputations among the French soldiers, ${ }^{171}$ compared with a maximum of 1353 in the British army. Even allowing for this difference, it would appear that the French, perhaps after some initial qualms as described by Macleod and Flowers, used chloroform more liberally than did the British.

The Russians probably used anaesthesia much more extensively than either the British or the French. An anonymous correspondent to the Lancet was told by Russian medical officers who were captured after the surrender of Bomarsund that "they perform every operation with chloroform, no matter how trivial it might be". ${ }^{172}$ This statement is corroborated in the writings of Pirogov, the senior Russian surgeon in Sebastopol, who used anaesthetics not only for operations but also for examinations where no operation was planned. ${ }^{173}$

\section{Selective Anaesthesia-an Anglo-Saxon phenomenon?}

To those of us living at the end of the twentieth century it may come as a surprise to find that, eight or nine years after its introduction, anaesthesia was not in universal use throughout the Crimean War. It cannot have been due to ignorance for, although the surgeons of the British army in the mid-nineteenth century spent much of their

\footnotetext{
165 Macleod, op. cit., note 20 above, p. 992.

166 Flower, op. cit., note 143 above, p. 309.

167 Prof. Mounier, 'On the employment of chloroform in the army in the east', Med. Times Gaz., 1855, i: 605 .

168 Osborne, op. cit., note 103 above.

${ }^{169} \mathrm{G}$ H B Macleod, Notes on the surgery of the war in the Crimea, 2nd ed. London, John Churchill,
}

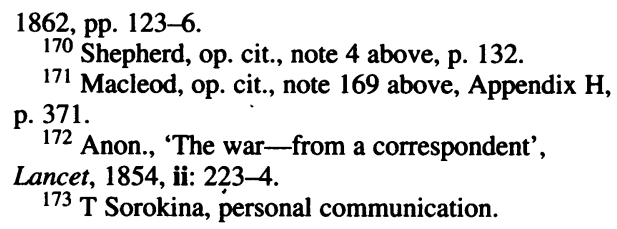

${ }^{173} \mathrm{~T}$ Sorokina, personal communication. 


\section{The Use of Chloroform during the Crimean War}

professional careers abroad and often in remote areas, many were frequent contributors to medical journals. Moreover, by the second half of the war, they must all have had many opportunities of witnessing anaesthesia at first hand and of learning the techniques from others, even if they had no previous practical experience. Concerns about the use of anaesthesia in the "shock" which followed severe gun-shot wounds, and of the risk-benefit ratio in more minor injuries, were matters of professional judgement which must also have exercised the minds of the French and Russian surgeons; why then did the British surgeons use chloroform less liberally than their French and Russian counterparts? The answer to this question lies, perhaps, in different social and cultural perceptions of pain, rather than in any difference in professional judgements. In mid-nineteenth-century America, another country with at that time a predominantly Anglo-Saxon population, Pernick has shown how the use of anaesthesia was influenced by the age, sex, ethnicity and occupation of the patient. ${ }^{174}$ Thus adolescents and adults were less likely to receive anaesthesia than children or the elderly, men less likely than women, immigrants less likely than those born in America, and sailors and labourers less likely than those in all other occupations. At the Massachusetts General Hospital, anaesthesia was used for all major amputations, but the private records of Dr F H Hamilton show that between 1849 and 1877 he used anaesthesia for major limb amputations in only 74 per cent of males aged between 11 and 74 years, and at the Pennsylvania Hospital between 1853 and 1862 only 67 per cent of males with "fracture amputations" were anaesthetized. These percentages are similar to the 76 per cent of British soldiers who were anaesthetized for major amputations during the Crimean War. Indeed, when one considers that the data collected by Pernick relate to all males, whatever their occupation, and that seamen and labourers in the Hamilton and Pennsylvania series were less likely to receive anaesthesia than those in all other occupations, the rate of usage among British soldiers is probably greater than in these two American series.

In the first half of the nineteenth century soldiers were expected to be able to withstand pain, and Pernick suggests that it was only in the mid-1850s that Anglo-American textbooks of surgery and medicine began to reject this notion and to suggest that soldiers merited anaesthesia on the same terms as did other men. Thus, during the war with Mexico (1846-1848) the chief surgeon of the American hospital at Vera Cruz claimed that chloroform was unnecessary on the field of battle, and he prevented a civilian surgeon from using chloroform in his hospital. Thirteen years later, during the American Civil War (1861-1865), attitudes had begun to change, though Pernick quotes Louisa May Alcott, who described how one surgeon, a veteran of the Crimean War, used ether only for amputations, and how a soldier's chances of receiving anaesthesia varied greatly depending on the opinions of the medical officer on duty.

Were British soldiers less likely to receive anaesthesia than their non-military compatriots at the time of the Crimean War? If selective anaesthesia was being practised, then differences might be found between military and non-military men in the use of anaesthesia for dental extractions which, although painful, are usually relatively brief and minor procedures. This hypothesis can be tested by examining the Casebooks of Dr John

\footnotetext{
${ }^{174}$ M S Pernick, A calculus of suffering, New York, Columbia University Press, 1985, esp.
}

pp. 150-1, 176-7, 181-5, 190-5, and Appendix, pp. 249-61. 


\section{Henry Connor}

Snow, which cover the period from 17 July 1848 to 5 June $1858 .{ }^{175}$ The data shown in Table 9 compares the number of anaesthetics given by Snow for dental and non-dental procedures in soldiers and sailors with those given to non-military men. Military and naval patients were identified either by the mention of a rank (e.g. captain or general), or by the description of the patient as a soldier or sailor, or by the operation having taken place in a military hospital. Children under the age of sixteen years have been excluded from the analysis. The use of anaesthesia for dental procedures was similar in military and naval patients (9.2 per cent of all anaesthetics) to that in non-military and non-naval men (11.6 per cent), even though the average number of teeth extracted at each procedure was smaller in the military and naval men. This data does not support the hypothesis that British soldiers and sailors were less likely to receive anaesthesia for minor procedures than their civilian colleagues. ${ }^{176}$ It is, however, of interest that seven of the thirteen dental anaesthetics in the military and naval men were given in just one year, between 17 July 1856 and 16 July 1857 . Thus in the eight years before the end of the Crimean War dental anaesthetics accounted for 4.8 per cent of the total, and in the subsequent two years for 21 per cent of all anaesthetics in military and naval men $\left(\mathrm{Chi}^{2}=8.7,2 \mathrm{p}<0.02\right)$. Whether this difference reflects a greater demand for anaesthesia among soldiers who had witnessed its use in the Crimea, or a greater prevalence of dental caries after two years of the hardships of war cannot be determined from this data.

Table 9

Dental and non-dental anaesthetics given by Dr John Snow

\begin{tabular}{lcccc}
\hline & \multicolumn{2}{c}{ Civilian Men } & \multicolumn{2}{c}{ Military and naval men } \\
\hline & Non-dental & Dental & Non-dental & Dental \\
\hline All cases (n) & 1363 & 179 & 129 & 13 \\
Dental cases as \% of all cases & & 11.6 & & 9.2 \\
Average number of teeth extracted & 3.1 & & 1.8 \\
Excluding cases where $>3$ teeth extracted: & & & \\
as $\%$ of all cases & 116 & & 12 \\
\hline
\end{tabular}

${ }^{175}$ R H Ellis (ed.), The case books of Dr John Snow, Medical History, Supplement No. 14, London, Wellcome Institute for the History of Medicine, 1994. As Ellis points out in his Introduction, the Case Books are not a totally comprehensive record of Snow's anaesthetic workload, but they probably document the great majority of the anaesthetics which he gave from mid-July 1848 until his death. Only the cases described in his Case Books are included in this analysis; details of other cases can be found in the bibliography of Snow's publications in:
D A E Shephard, John Snow: anaesthetist to a queen and epidemiologist to a nation, Cornwall, Canada, York Point Publishing, 1995, Appendix II, pp. 299-304.

${ }^{176}$ It is not possible to make similar comparisons between men and women using Snow's case records, because the nature of the non-dental anaesthetics is very different between the two sexes, and also because women had a greater number of teeth extracted under each anaesthetic (3.9 compared with 3.0). 


\section{The Use of Chloroform during the Crimean War}

What of the soldiers' own wishes as to whether they should be given anaesthesia? References to this subject in the Crimean War are scanty and anecdotal. In the case of the patient who died under anaesthesia the chloroform seems to have been given at the soldier's own express request, ${ }^{177}$ and a correspondent to the Lancet mentioned that "many of the poor fellows were cunning enough to ask for chloroform". ${ }^{178}$ Whether any of the patients refused chloroform is not recorded, although a few soldiers did so at the time of the second Anglo-Boer war nearly fifty years later. ${ }^{179}$

\section{Medical Opinion in later Years}

In 1875 Surgeon-Major Joshua Porter published The surgeon's pocket book-being an essay on the best treatment of the wounded in war. Porter had battlefield experience in the Crimea, during the Indian mutiny, and in the Franco-German war of 1870-71, and at the time of publishing his book was assistant professor of military surgery in the Army Medical School at Netley. It is therefore probable that his opinions were respected and represented orthodox thinking among the army surgeons of the time. Porter advised that, when possible, chloroform should be used for all operations, and even for dressing painful wounds. Among the usual precautions which should be observed when using chloroform he included the "wishes of the patient". Whether this was an injunction to any surgeons who did not routinely use chloroform to give it if it was requested by the patient, or whether it was meant to imply that chloroform should be omitted if the patient did not wish it, is not clear from the text. He stated categorically that chloroform "decidedly relieves the nervous shock" in recently wounded soldiers. So valuable was chloroform that it "and other anaesthetics should be most carefully treasured by the army surgeon and no waste allowed. It is sometimes difficult to procure it in sufficient quantity, especially after severe engagements, when every drop is worth its weight in gold". ${ }^{180}$

During the Crimean War it would seem that chloroform was the only anaesthetic agent which was used, ${ }^{181}$ but Porter's mention of "other anaesthetics" implies that it was no longer the sole anaesthetic in use by the army in 1875 . He goes on to say that he, himself, had frequently used ether and found it highly satisfactory. Ether had the reputation, especially among Americans, of being much safer than chloroform, but the greater volume required to produce anaesthesia and the necessity of carrying a bulky inhaler for its administration were disadvantages on active service. Porter suggested that it was a matter for debate as to whether these disadvantages should prevent its use in warfare, noting that, "our combatant brethren never hesitate to transport enormous implements of destruction!".

In 1878 the Surgeon General's Office in Simla published memoranda for the use of Medical Officers in the British Forces which included details of stocks of chloroform to be held at regimental and divisional levels (Table 10). Regimental stocks were twice as

\footnotetext{
${ }^{177}$ Medical and surgical history, op. cit., note 21 above, pt 2, pp. 268-9.

178 Anon., 'The war', Lancet, 1855, i: 22.

179 B Hovell, 'Anaesthesia and the siege of Ladysmith', History of Anaesthesia Society Proc., 1994, 15: 55-8.

180 J H Porter, The surgeon's pocket book, London,
} 


\section{Henry Connor}

Table 10

Recommended regimental and divisional stocks of chloroform in 1854 and 1878

$1854^{\mathrm{a}}$

$0 \mathrm{lb}=8 \mathrm{oz}$

Regimental

Divisional

Field Hospital

Base Hospital
$10 \mathrm{lb}=0 \mathrm{oz}$ $1878^{b}$

$1 \mathrm{lb}=0 \mathrm{oz}$

$10 \mathrm{lb}=0 \mathrm{oz}$

$20 \mathrm{lb}=0 \mathrm{oz}$

Sources: ${ }^{a}$ Lancet, 1854, ii: 517-18. RAMC 397 FRS 1/2, 1/13a and 1/15, see note 30 above.

bLongmore Pamphlets, RAMC 423, vol. 5, Paper 32, see note 27 above.

great and divisional stocks three times greater than during the Crimean War, which suggests that anaesthesia was now more generally used and that previous stock levels had proved inadequate. No mention was made of other anaesthetic agents, so it seems probable that chloroform was still considered to be the recommended anaesthetic in the British army. The increasing use of anaesthesia in the army during these years mirrored what was happening in civilian practice, and was probably the result of changing social concepts, influenced both by the evangelical abhorrence of unnecessary pain and by a more pragmatic, Benthamite approach to scientific progress. ${ }^{182}$

Although concerns about aggravating shock and "failure to rally" from chloroform appear to have disappeared in the years after the Crimean War, they resurfaced during the First World War (1914-18). In a manual published in 1918, army surgeons were advised to avoid chloroform in septic cases requiring amputation "as it is often followed by a slow fall of blood pressure, which ends in death during the twelve hours succeeding operation". ${ }^{183}$ Gas and oxygen was recommended as the method of choice in such cases, though spinal anaesthesia, warm ether vapour and intravenous ether were regarded as comparatively safe alternatives.

\section{Conclusions}

At the start of the war British army surgeons had little experience of using anaesthesia in patients with gunshot wounds, and opinion was divided about the possible "depressive" effect of chloroform in such injuries. During the first three months of the war, chloroform was used in only 60 per cent of all amputations and in 66 per cent of major amputations. Lack of availability of chloroform, especially at regimental level and on transport ships, was probably the major reason for its low usage at this time; John Hall's caution against its use probably had only a limited impact and then only in divisions or regiments where the opinions of the senior medical officers concurred with his.

182 C Lawrence, 'Democratic, divine and heroic: the history and historiography of surgery', in Lawrence (ed.), op. cit., note 150 above, pp. 1-48.
183 Anon., Injuries and diseases of war, London, HMSO, 1918, p. 48. 


\section{The Use of Chloroform during the Crimean War}

During the second quarter of the war chloroform was used in 95 per cent of all amputations and 100 per cent of major amputations. At this time, during the winter months, there was little fighting and operations were few in number. Supplies of chloroform were obviously adequate for the relatively small demand, and medical staff had sufficient time to use anaesthesia. However, these considerations also applied during the last three months of the war, and the high rates of use during the first quarter of 1855 may also have been influenced by public reaction at home to the publication of Hall's memorandum and general concern about the plight of the British soldier in the Crimea.

After March 1855 the use of anaesthesia declined progressively, and by the end of the war was at the same level as it had been at the start. Low rates of usage at times of intense fighting, for example, during the final attack on the Malakoff and Redan redoubts in September 1855, may have resulted from temporary, local shortages of chloroform, even though total stocks were ample, and from pressure of work. However these considerations did not apply between October and December 1855, when the surgical workload was relatively light and there were no sudden peaks due to major military actions. Medical opinion and practice must have been the major determinants of chloroform usage at this time.

By the end of the war most surgeons no longer believed that chloroform had a "depressant" effect in shock, and some realized that, as Snow had predicted in 1847, the relief of pain had a positively beneficial effect in apparently poor risk patients, thereby permitting primary operations which carried lower mortality rates than delayed, secondary procedures. However, a significant minority, probably about a third of army surgeons, still considered that chloroform had a depressant effect which contributed to "failure to rally" from an operation; these surgeons were generally averse to using chloroform in amputations which carried a high mortality, such as those in the thigh. There was still considerable reluctance to use chloroform for minor operations where the injury itself posed no risk to life.

The official medical history of the war omitted all mention of quantitative data about the use of chloroform, and was phrased in such a way as to suggest that anaesthesia had been practised more widely than was the case. This probably reflects continuing sensitivity to the general criticisms to which the Army Medical Service had been subjected during the war, and also a reluctance to give information which might lead to a revival of public discussion about Hall's caution on the use of chloroform.

In contrast to American practice in the mid-nineteenth century, there is no known surviving evidence to suggest that British soldiers and sailors were less likely to receive anaesthesia than were civilian men. The British usage of anaesthesia during the Crimean War was similar to that in contemporary American civilian practice, though lower than that in the Russian army in the Crimea, and probably lower than in the French army.

In the years following the war, the use of anaesthesia by British army surgeons appears to have increased; by the mid-1870s military surgeons were officially advised to use chloroform whenever possible, and the stocks held at regimental and divisional levels had been increased two- to three-fold. The increase in the use of anaesthesia mirrored what was happening in civilian practice at this time. 